\title{
Inżynier Kajetan Mościcki ( $1855-1933)$ i jego działalność na rzecz budowy ulic i mostów Warszawy
}

\section{Engineer Kajetan Mościcki (| 855-| 933) and his Activity for the Construction of Warsaw Streets and Bridges}

The article presents the problems of building and maintaining urban transport infrastructure in Warsaw at the turn of the $20^{\text {th }}$ century. The text concerns Kajetan Mościcki (1855-1933), engineer, who was appointed by the acting Mayor of Warsaw, General Sokrates Starynkiewicz, to the position of senior city engineer and head of the municipal construction department, where he worked from 1889 to 1909. During this period, he paved the streets which were worn or damaged by sewerage works with wooden blocks and covered the sidewalks with concrete slabs. He designed the first slip road in the Kingdom of Poland in the form of a spiral, and he also participated in the construction of the oldest road engineering structures made of reinforced concrete, located in Ujazdowski Park and on Karowa street in Warsaw, the first Warsaw power plant and the second city bridge across the Vistula. In addition to his professional activity, Kajetan Mościcki was an inventor in the fields of mechanics and electrical engineering. At the end of his life, he founded an award that the Polish Academy of Arts and Sciences was to grant to Polish scientists for outstanding achievements.

Keywords: streets, wooden pavement, bridges, reinforced concrete, electrification, inventiveness

Słowa kluczowe: ulice, bruk drewniany, mosty, beton zbrojony, elektryfikacja, wynalazczość

Na przełomie XIX i XX w., kiedy na mapach politycznych świata nie można było odnaleźć Polski, a jej stolicę Warszawę traktowano jak jedno z wielu gubernialnych miast olbrzymiego Imperium Rosyjskiego, inżynierowie Polacy angażowali się w tworzenie materialnych podstaw bytu społeczeństwa. Ich dzieła, o ile nie uległy zniszczeniu podczas dwóch wojen światowych, po dzień dzisiejszy oddziałują na polską kulturę, naukę lub gospodarkę. In- 


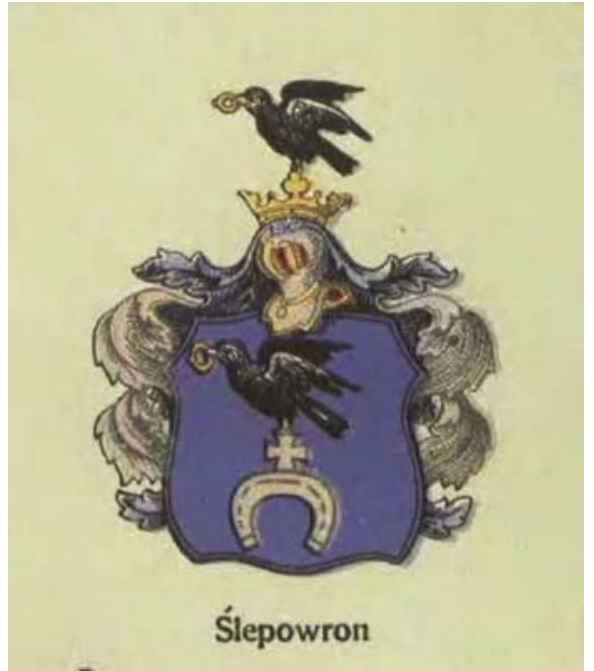

Ryc. 1. Herb "Ślepowron" Mościckich wg: Zbigniew Leszczyc, Herby szlachty polskiej, Poznań 1908, (Internet Archive). żynier Kajetan Mościcki był jednym z obecnie mało znanych twórców infrastruktury technicznej miasta stołecznego Warszawy. Jego osobie poświęcono dwie notki biograficzne, które zostały zamieszczone w Polskim Słowniku Biograficznym ${ }^{1}$ i w Stowniku Biograficznym Techników Polskich². Ujmując biografie w sposób zwięzły, ich autorzy nie mogli uwzględnić wielu dostępnych informacji źródłowych. Celem niniejszego artykułu jest zebranie dostępnych źródeł, dotyczących działalności zawodowej inżyniera Mościckiego, w szczególności na rzecz rozwoju miejskich ulic i mostów oraz próba ich interpretacji.

Kajetan Kazimierz Mościcki urodził się 4 marca 1855 r. w majątku Dołęgi, położonym w okolicach Łomży, na ziemiach Królestwa Polskiego pod zaborem rosyjskim. Jego ojcem był Apolinary Mościcki herbu Ślepowron (Ryc. 1), wójt gminy i sędzia pokoju, a matką Elżbieta Mościcka z Dąbrowskich³. Rodzina Mościckich osiadła w zakupionych przez Apolinarego dobrach Ławsk w Okręgu Biebrzańskim powiatu łomżyńskiego ${ }^{4}$. Kajetan Mościcki uczył się w "gimnazjum męzkiem klassycznem V, przy ulicy Zielnej" w Warszawie, gdzie 28 czerwca 1872 r. uzyskał tak zwany „patent ukończonego kursu nauk”. Będąc absolwentem gimnazjum podjął studia na Wydziale Fizyko-Matematycznym Cesarskiego Uniwersytetu Warszawskiego ${ }^{6}$. Studiował tam do 1873 r., a następnie wyjechał do Petersburga, gdzie kontynuował edukację w Instytucie Inżynierów Komunikacji, który ukończył w 1878 r., uzyskując dyplom inżyniera komunikacji

Już jako dyplomowany inżynier, Kajetan Mościcki zatrudnił się w charakterze pomocnika maszynisty, a następnie maszynisty na Kolejach Południowo-Zachodnich w Rosji. Równocześnie pracował twórczo, publikując artykuły na temat matematyki czy statyki budowli w wydawanym w Warszawie „Przeglądzie Technicznym”8. W 1883 r. Kajetan Mościcki

1 J. Piłatowicz, S. Świerzewski, Mościcki Kajetan Kazimierz, [w:] Polski Słownik Biograficzny t. 22/1, 1977, s. $149-150$

2 B. Chwaściński, Mościcki Kajetan Kazimierz, [w:] Słownik Biograficzny Techników Polskich t. 7, 1996, s. 93-94.

3 M.J. Minakowski, Wielka genealogia Minakowskiego, Wielcy.pl [dostęp 7.06.2019]. Ponadto według Adama Ostrowskiego, Apolinary Mościcki był z zawodu inżynierem architektem i zajmował się w Warszawie handlem nieruchomościami, za: A. Ostrowski, Cmentarz parafialny w Wąsoszu, junosza.pl/wasos_cmentarz.html [dostęp: 22.03.2019].

4 Przed 1863 r. dobra Ławsk były własnością Jana Stanisława Wojczyńskiego, za: „Czytelnia Niedzielna” r. 5, 1860, nr 44, s. 374. Jan Stanisław Woyczyński (1831-1905), pod pseudonimem Jan Skarbek, uczestniczył w powstaniu styczniowym, a po jego upadku i po powrocie z emigracji był represjonowany przez władze carskie.

5 „Kurjer Warszawski" r. 52, 1872, nr 141, s. 2.

6 Ś. p. inż. Kajetan Mościcki, „Świat” r. 28, 1933, nr 44, s. 20.

7 Wykształcenie techniczne, „Przegląd Techniczny” r. 4, 1878, t. 7, s. 253.

8 K. Mościcki, O siłach poprzecznych powstających przy zgin. belek, „Przegląd Techniczny” r. 8, 1882, t. 15, s. 55-57; idem, Kilka słów o rozwiązywaniu równań stopni wyższych, „Przegląd Techniczny” r. 8, 1882, t. 15, s. 72-77. Zob. E. Wawrykiewicz, Bibliografia trzydziestu siedmiu tomów Przeglądu Technicznego za lat XXV (1875-1899), Warszawa 1903. 
powrócił na ziemie polskie na stałe podejmując pracę konstruktora na budowie drogi żelaznej Iwanogrodzko(Dęblińsko)-Dąbrowskiej. Zapewne doświadczenie zdobyte na tej budowie przyczyniło się do powierzenia mu w 1886 r. stanowiska wicedyrektora kolei Fabryczno-Łódzkiej, które zajmował do 1889 r. ${ }^{9} \mathrm{~W}$ „Przeglądzie Technicznym” opublikował dwa artykuły, tym razem z dziedzin mechaniki i elektrotechniki. W drugim z artykułów inżynier Mościcki jako pierwszy w Imperium Rosyjskim przedstawił projekt samodziałającej łącznicy telefonicznej ${ }^{10}$.

Obowiązki prezydenta miasta Warszawy pełnił wówczas rosyjski generał Sokrates Starynkiewicz (1820-1902), a sprawami technicznymi w mieście kierował starszy inżynier Alfons Grotowski (1833-1922), członek Komitetu Budowy Kanalizacji i Wodociągów miasta Warszawy, wcześniej projektant i budowniczy wodociągu praskiego. Na obszarze lewobrzeżnej Warszawy była prowadzona budowa wodociągów i kanalizacji, którą początkowo kierował angielski inżynier William Lindley (1808-1900). W związku z jego przejściem na emeryturę, obowiązki kierownika przejmowali trzej synowie William Heerlein Lindley (1853-1917), Robert Searles Lindley (1854-1925), a od grudnia 1888 r. Joseph IV Lindley (1859-1906), który na swojego zastępcę oraz naczelnego inżyniera kanalizacji i wodociągów wyznaczył inżyniera Grotowskiego ${ }^{11}$. W konsekwencji powstał wakat na stanowisku starszego inżyniera miasta Warszawy, a Kajetan Mościcki został kandydatem na jego obsadzenie. Już 19 lutego 1889 r. w dodatku porannym „Kurjer Warszawski” donosił, że „P. Mościcki w celu obznajmienia się z interesami miasta i rodzajem służby, od kilku dni już pracuje w wydziale budowlanym magistratu". Nie będąc pewnym decyzji zarządu miejskiego, autor artykułu zastrzegał; „Kwestja jednakże obsadzenia posady głównego inżeniera nie może jeszcze stanowczo być przesądzoną"12.

Obejmując na przełomie lutego i marca 1889 r. stanowisko starszego (nazywanego również naczelnym lub głównym) inżyniera miasta Warszawy, a jednocześnie naczelnika kierującego pracami wydziału budowlanego magistratu, Kajetan Mościcki przejął odpowiedzialność za stan warszawskich ulic. Przeważająca część jezdni tych ulic „brukowana była starym sposobem $\mathrm{w}$ podłużne ławy z bardzo grubego polnego kamienia, między któremi brukowano drobniejszym kamieniem różnej wielkości"13. Ponadto w Warszawie użytkowano jezdnie wykonane z kostki kamiennej, z żelaznych tafli, makadamowe ${ }^{14}$ i żwirowe. Wiele ulic zostało uszkodzonych podczas wykonywania i zasypywania głębokich wykopów przy budowie wodociągów lub kanalizacji. Z naprawami rozkopanych nawierzchni wstrzymywano się jednak do czasu zakończenia procesu osiadania zasypek gruntowych. Niebawem potrzebą chwili stać się miało polepszenie stanu warszawskich ulic.

9 B. Chwaściński, op. cit.

10 K. Mościcki, Maszyny dwutłokowe o przemiennem działaniu, „Przegląd Techniczny” r. 14, 1888, t. 25, s. 49-53, 74-79; idem, Samodziałające komutatory centralne dla komunikacyi telefonicznych i telegraficznych, „Przegląd Techniczny" r. 14, 1888, t. 25, s. 169-173, 203-208, 232-235. Zob. E. Wawrykiewicz, op. cit. Także: J. Piłatowicz, S. Świerzewski, op. cit.

11 A. Słoniowa, Początki Nowoczesnej Infrastruktury Warszawy, Warszawa 1978, s. 71.

12 „Kurjer Warszawski” r. 69, 1889, nr 50 Dodatek poranny, s. 1-2.

13 Z. Sznuk, Bruki i sposób gospodarowania niemi w Warszawie, „Przegląd Techniczny” r. 43, 1917, nr 25-26, s. 215.

14 Nawierzchnie z łamanego kruszywa kamiennego, układane w jednofrakcyjnych warstwach - od największej do najmniejszej frakcji, zagęszczane przez wałowanie, które około 1820 r. zostały wynalezione przez szkockiego inżyniera Johna Loudona McAdama (1756-1836). 


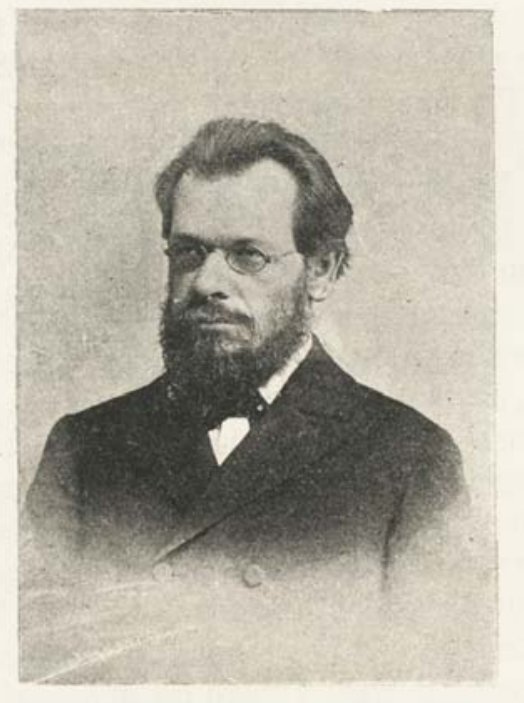

Inż. Kajetan Mościcki, wice-prezes.

Ryc. 2. Fotografia Kajetana Mościckiego w "Tygodniku Illustrowanym" z 1896 r. (Mazowiecka Biblioteka Cyfrowa).
W numerach 25-26, 29-30 i 33-34 „Przeglądu Technicznego" z 1917 r. inżynier Zdzisław Sznuk (1859-1943) ${ }^{15}$ opublikował artykuł pt. Bruki i sposób gospodarowania niemi w Warszawie, w którym czytamy, że „właściwa historya bruków rozpoczyna się w r. 1891 przy starszym inżynierze Kajetanie Mościckim". Prace brukarskie w Warszawie podjęto na jezdni Krakowskiego Przedmieścia, gdzie od lat była użytkowana kamienna kostka porfirowa ułożona na podsypce piaskowej. W ocenie inżyniera Sznuka zastosowany tam rodzaj kamienia wulkanicznego

jako bardzo twardy ze złomem muszlowym, łatwo się szlifuje, staje się ślizgi, przy znacznej powierzchni kostek i rzadkich spoinach konie mają mało punktów zaczepienia, wskutek czego ślizgały się i padały po każdym deszczu, wreszcie kanty kostek pod uderzeniami kół łatwo odpryskiwały, kostki bardzo prędko się zaokrąglały i stały się niemożliwe do jazdy ${ }^{16}$.

23 czerwca 1892 r. „Kurjer Warszawski” poinformował o przełożeniu torowiska tramwajów konnych „z powodu zamierzonego ułożenia bruku drewnianego, w miejsce obecnie istniejącego kamiennego, na Krakowskiem-Przedmieściu i jednoczesnego uregulowania trotuarów między Trębacką i Czystą"17. Prace prowadzone na tym odcinku miały się zakończyć około 22 października ${ }^{18}$.

Jezdnie tych odcinków warszawskich ulic, które wcześniej wybrukowano żelaznymi taflami w kształcie krat z otworami wypełnionymi żwirem, „były siedliskiem różnych zarazków oraz zbiornikami błota, obryzgującego przechodniów i pojazdy, przytem tafle te stały się jednym z artykułów stałego handlu dla złodziei i paserów"19. Komitet budżetowy miasta Warszawy zaplanował na 1893 r. wymianę żelaznych tafli, lecz wyłącznie na tych fragmentach jezdni, które sprawiały największe utrudnienia w ruchu. Z krytycznego artykułu Stefana Podkowy poświęconego budżetowi miasta dowiadujemy się, że

15 Syn inż. Sznuka, Stefan Mieczysław (1896-1986), generał brygady, pilot obserwator WP, w 1911 r. uczestniczył w skonstruowaniu pierwszego polskiego samolotu, walczył w wojnie z Rosją Sowiecką (1919-1920) i w kampanii wrześniowej 1939 r., a potem był m.in. szefem sztabu Inspektoratu Polskich Sił Powietrznych w Wielkiej Brytanii, szefem Polskiej Misji Wojskowej w Kanadzie, przewodniczącym Rady Kongresu Polonii Kanadyjskiej, Z. Kozak, Sznuk Stefan Mieczysław, [w:] Polski Słownik Biograficzny t. 48/3, 2012, s. 469-471.

16 Z. Sznuk, op. cit.

17 „Kurjer Warszawski” r. 72, 1892, nr 172 Dodatek poranny, s.1.

18 „Kurjer Warszawski" r. 72, 1892, nr 282, s. 4.

19 Z. Sznuk, op. cit.. Do 1925 r. na moście Kierbedzia użytkowano „płyty żeliwne wysokości 8cm, odlane w kratę ze ściankami grubości $2 \mathrm{~cm}$ i otworami w świetle $6 \times 8 \mathrm{~cm}$ ", zasypane żwirem, za: W. Gordziałkowski, Kostka drzewna jako materiał na nawierzchnię mostów dla ruchu kołowego, „Przegląd Komunikacyjny” 1945, nr 5, s. 150 . 
Projektowane są tam zamiany zniszczonych długoletnią egzystencją bruków żelaznych, na bruki z kostek porfirowych na ulicach: Saski plac, Czystej, Senatorskiej, Bielańskiej, Miodowej i Nowy Świat, ale wszędzie, jak na żarty, po kawałku ulicy!20

Wychodząc naprzeciw oczekiwaniom, w 1893 r. starszy inżynier miasta Warszawy, Kajetan Mościcki wprowadził nowe zasady dotyczące brukowania ulic: „pierwszorzędnych o ruchu lżejszym” - kostką drewnianą, a tak zwanych „arteryi towarowych” - kostką granitową. „Oba typy kładzione na podstawie betonowej 0,20 m grubości”21. Kierując się tymi zasadami przystąpiono do ułożenia bruku drewnianego na Nowym Świecie od ul. Królewskiej do ul. Świętokrzyskiej, o czym poinformował „Kurjer Warszawski” z 22 września 1893 r. $^{22}$ W kolejnym roku, 1894, wybrukowano jezdnie warszawskich ulic za kwotę 337950 rubli, a ponadto wydatkowano 123000 rubli na naprawy istniejących bruków. Wykonawstwo bruków drewnianych wraz z dostawą drewna wydział budowlany magistratu zlecił w drodze „licytacyi” dwóm firmom, kierowanym przez inż. P. Jarocińskiego (początkowo zatrudnionego w firmie francuskiej inż. Devarsa) i przez pana Marczenkę ${ }^{23}$. W ramach realizacji zleceń, na Krakowskim Przedmieściu kontynuowano wymianę kamiennej kostki porfirowej na kostkę drewnianą; od kwietnia 1894 r. w kierunku Nowego Światu, a od listopada na odcinku od ul. Trębackiej do placu Zamkowego ${ }^{24}$. Pomiędzy wrześniem 1894 r. a czerwcem 1895 r. sukcesywnie wymieniono bruk na ul. Nowy Świat ${ }^{25}$.

W 1892 r. wydział budowlany magistratu pod kierunkiem inżyniera Mościckiego i przy wsparciu prezydenta Sokratesa Starynkiewicza, kwotą 7800 rubli, zbudował i uruchomił fabrykę miejską wyrobów betonowych, która „tytułem próby” wykonała wyroby betonowe do kanalizacji i „tafle betonowe dla chodników”. Już w pierwszym roku funkcjonowania fabryki, wyprodukowano w niej płyty chodnikowe o łącznej powierzchni 299 sążni kwadratowych [1361 m² - M.M.], w 1895 r. dochodząc do produkcji na po-

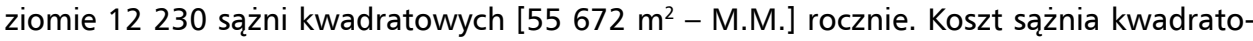
wego chodnika z tych płyt, ułożonych na podsypce piaskowej i zafugowanych zaprawą cementową, wyniósł 6 rubli i 40 kopiejek, a więc za $1 \mathrm{~m}^{2}$ zapłacono 1,41 rubla. W efekcie spadły ceny rynkowe podobnych wyrobów. Jednocześnie, Komitet Budowy Kanalizacji i Wodociągów miasta Warszawy zlecił okresowe badania kontrolne, których wyniki wskazywały, że jakość wyrobów, wyprodukowanych przez miejską fabrykę, była wyższa od jakości wyrobów dostarczanych przez firmy prywatne. „Próbki z masy betonowej, przygotowanej w postaci prawidłowych sześcianów jednakowych wymiarów gniotły się pod ciężarem: z fabryki Devarsa - 15,8 pudów, [z fabryki - M.M.] Gagatnickiego - 26,9 pudów, [z fabryki - M.M.] miejskiej - 31,9 pudów." - pisał na łamach „Przeglądu Tygodniowego” inżynier Mościcki, naczelnik wydziału budowlanego magistratu26. Do badania jakości płyt chodnikowych i innych wyrobów budowlanych naczelnik Mościcki utworzył laboratorium Pięknych" r. 28, 1893, nr 10, s. 110-111.

21 Z. Sznuk, op. cit.

22 „Kurjer Warszawski” r. 73, 1893, nr 262, s. 1.

23 Z. Sznuk, op. cit., s. 215-216.

24 „Kurjer Warszawski” r. 74, 1894, nr 98, s. 4; nr 299, s. 3.

25 „Kurjer Warszawski” r. 74, 1894, nr 266, s. 4; r. 74, 1894, nr 282, s. 5; r. 75, 1895, nr 167, s. 4.

26 K. Mościcki, Polemika. Sprawy miejskie, „Przegląd Tygodniowy” r. 31, 1896, nr 11, s. 131. 

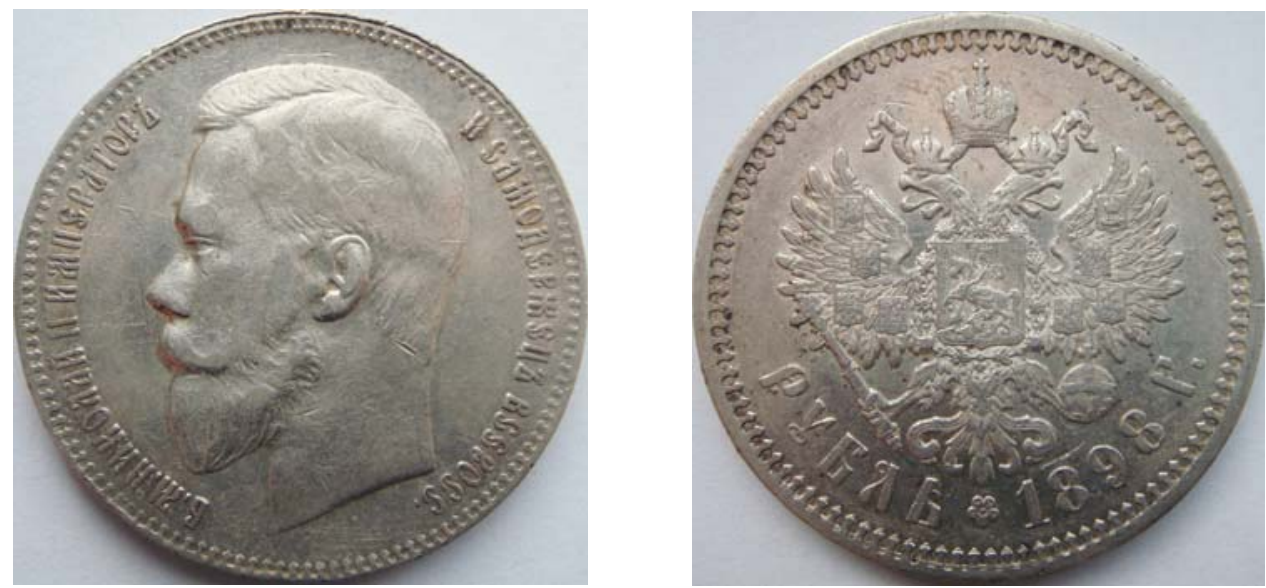

Ryc. 3. Rubel wybity w srebrze w 1898 r., z podobizną panującego cara Mikołaja II na awersie i z orłem Królestwa Polskiego pośrodku lewego skrzydła orła Imperium Rosyjskiego na rewersie (ze zbiorów autora).

mechaniczne, którego działalnością interesowała się również warszawska prasa. „Do prób z materjałami, używanemi do robót brukarskich, szosowych i t. p. magistrat postanowił nabyć aparat «Essayeuse d'usure systéme Dorry», za cenę 600 rs. [rubli srebrnych - M.M.]" (Ryc. 3), donosił „Kurjer Warszawski" z 13 sierpnia 1896 r."27

Wydział budowlany magistratu zajmował się również oznaczaniem „właściwych cen normalnych", wykorzystywanych w planowaniu budżetu i przy zlecaniu przez miasto robót budowlanych, obejmujących m.in. nawierzchnie ulic i chodników, bulwarki, kanalizację i wodociągi. Zbierał w tym celu „informacye i cenniki od firm pierwszorzędnych” i przekazywał je do rozpatrzenia przez komisję, w której zasiadali wszyscy technicy miejscy, a ponadto znani specjaliści, przemysłowcy, przedsiębiorcy i właściciele większych domów handlowych. Komisja ustalała obowiązujące ceny normalne w drodze konsensusu ${ }^{28}$.

W kierowanym przez naczelnika Mościckiego wydziale był sukcesywnie aktualizowany plan regulacyjny miasta „sporządzony przez b. komitet regulacyjny, który rozpoczął czynności swoje przed 1860 r. i funkcyonował lat kilka"29. Intensywny wzrost liczby mieszkańców Warszawy (od 243512 osób w 1866 r. i 553643 w 1896 r. do 764054 w 1909 r. $)^{30}$, stymulował budowę czynszowych kamienic, hal targowych i fabryk przez prywatnych właścicieli gruntów oraz generował nowe potrzeby komunikacyjne, których zaspokojenie leżało po stronie władz miasta. Wychodząc naprzeciw tym potrzebom, tylko w latach 1893-1895 w wydziale budowlanym przeprowadzono regulację 8 nowych ulic i skorygowano przebiegi 26 ulic istniejących. Prace te dotyczyły między innymi nowej ulicy wyznaczonej na gruntach po byłej walcowni na Koszykach oraz istniejących ulic Oboźnej i Karowej. Obejmowały one wykonanie pomiarów geodezyjnych, pertraktacje z zaintere-

27 „Kurjer Warszawski” r. 76, 1896, nr 223 Dodatek poranny, s. 1.

28 K. Mościcki, Polemika. Sprawy miejskie, nr 12, s. 155.

29 Ibid., s. 143.

30 M. Nietyksza, Ludność Warszawy na Przełomie XIX i XX wieku, Warszawa 1971, s. 26-27. Także: W. Dziewulski, H. Radziszewski, Warszawa, Warszawa 1913, tablica nr 1. 
sowanymi właścicielami gruntów i dopełnienie niezbędnych formalności. Do właściwego oszacowania wartości gruntów przejmowanych z rąk prywatnych przez zarząd miejski, każdorazowo powoływano niezależną komisję wyłonioną z grona znanych obywateli miasta $^{31}$. W kolejnych latach mieszkańcy Warszawy zawdzięczali inżynierowi Mościckiemu powstanie nowych ulic: Szopena (obecnie Fryderyka Chopina), Natolińskiej, Inżynierskiej i Służewskiej oraz przebudowę ul. Długiej i Nowego Zjazdu².

W marcu 1896 r. wydział budowlany magistratu składał się „z kilkunastu inżynierów z wykształceniem akodemickiem, posiadających wieloletnią i wielostronną praktykę, oddanych wyłącznie służbie miejskiej, niepozwalającej ze względu na ogrom pracy, na zaję-

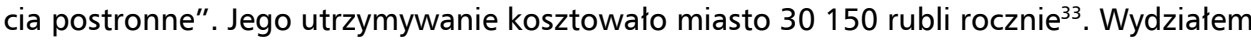
kierował starszy inżynier miasta Warszawy, o którym Aleksander Głowacki herbu Prus (1847-1912), publikujący artykuły prasowe pod pseudonimem Bolesław Prus w „Kuryerze Codziennym" napisał,

że inżynier Mościcki, który podobno nie odznacza się nektarową słodyczą i ma być okrutnie twardy, gdy idzie o najmniejszy uszczerbek dla dochodów miasta, że pan ten posiada w Warszawie dziwnie ustaloną opinię. Kogokolwiek zapytałem, każdy z fonograficzną dokładnością odpowiadał, że: P. Mościcki, jako fachowiec, jest wzorem ścisłości. Na jego zdanie, zawsze oparte na sumiennych studyach, można godzić się z zamkniętemi oczyma. Jako zaś człowiek, p. M. cieszy się reputacyą nieskazitelnie uczciwego, prawie ascety i trochę dziwaka ${ }^{34}$.

Od lutego do kwietnia 1896 r. przez warszawską prasę przetoczyła się fala krytyki w odniesieniu do sposobu prowadzenia wymian nawierzchni ulic. „Jeżeli powiadacie, że dzięki zabiegom wydziału budowlanego powiodło się ceny bruku drewnianego zredukować prawie o połowę, to ani my, ani nikt z doświadczonych inżynierów, zwycięztwa żadnego nie przyzna, ani też brawa bić nie będzie”, pisał „Przegląd Tygodniowy”, przedstawiając poglądy osoby podpisanej Wł. Skij5 - zapewne przedsiębiorcy pozostającego pod wrażeniem przegranego przetargu. „Rodzaj bruku jak już poprzednio wspominaliśmy, przyjął się w Warszawie jaknajgorszy", wtórował mu tygodnik literacko-społeczno-polityczny „Głos”. „Trwałość takiego bruku, przy najstaranniejszem wykonaniu i stałej konserwacji, nie przenosi lat 5", bezpodstawnie twierdził autor artykułu. Koszt jego wynosi 7,90 rs. sążeń kw. [1,74 rubla srebrnego za $1 \mathrm{~m}^{2}$ - M.M.]"36. Pomimo tej krytyki, kontynuowano wymiany nawierzchni według zasad ustalonych przez inż. Mościckiego. We wrześniu 1897 r. na ul. Marszałkowskiej, od ul. Widok do Alei Jerozolimskich, kostkę

31 K. Mościcki, Polemika. Sprawy miejskie, nr 12, s. 143.

32 L. Belmont, Na kanwie skargi do I-go Departamentu Senatu, „Wolne Słowo” r. 5, 1912, nr 167-168, s. 26.

33 „Przegląd Tygodniowy” r. 31, 1896, nr 13, s. 155.

34 B. Prus, Kronika tygodniowa, „Kuryer Codzienny” r. 33, 1897, nr 101, s. 1. Bolesław Prus jest uznawany za autorytet moralny Polaków z przełomu XIX i XX w. Represjonowany przez Rosjan odebraniem polskiego szlachectwa za udział w powstaniu styczniowym 1863 r., swój herb rodowy przyjął jako pseudonim literacki. Był dziennikarzem satyrycznej „Muchy”, „Kurjera Warszawskiego”, „Tygodnika Illustrowanego”, „Nowin” , "Kraju”, „Wędrowca” i „Kuryera Codziennego”, w którym prowadził Kronikę tygodniową. Dziennikarska znajomość realiów życia w Warszawie i w Królestwie Polskim posłużyła powstaniu wielu nowel oraz wielkich dzieł literackich pt.: Placówka, Lalka, Emancypantki, Faraon, Dzieci.

35 Sprawy miejskie, „Przegląd Tygodniowy” r. 31, 1896, nr 8, s. 89.

36 Bruki warszawskie, "Głos” t. 1, 1896 r., nr 15, s. 353-354. 
granitową z Norwegii, położoną tam około 1878 r. zastąpiono brukiem drewnianym ${ }^{37}$. W 1898 r. rozpoczęto brukowanie drewnem Alei Ujazdowskich, planując zakończenie robót w dwóch etapach: pierwszym - do Placu na Rozdrożu w 1899 r., drugim - do pałacu Belwederskiego w 1900 r. ${ }^{38}$

Zainteresowanie inżyniera Mościckiego wzbudzały nawierzchnie bitumiczne, stosowane w zachodniej Europie. Już w 1894 r. „Kurjer Warszawski” informował mieszkańców, że

W zarządzie miejskim powstał projekt wylania niektórych ulic asfaltem. W tym celu zawiązano korespondencję z miastami zagranicznemi, gdzie bruki asfaltowe są więcej rozpowszechnione, a mianowicie z Berlinem, zkąd magistrat zażądał wiadomości o cenie bruku asfaltowego, o firmach, które go wykonywają i o wytrzymałości tego rodzaju bruków ${ }^{39}$.

Zapewne po uzyskaniu tych informacji, w latach 1895-1896 po raz pierwszy w Warszawie na dwóch ulicach ułożono nawierzchnie z tzw. asfaltu prasowanego lub według innej nazwy asfaltu tłoczonego ${ }^{40}$. Na ul. Mazowieckiej wykonała je firma Reh \& Co., stosując włoski asfalt San-Valentino, a na ul. Brackiej warszawskie przedsiębiorstwo B-ci Rotmil, z użyciem asfaltu Limer. Ceny tych robót okazały się wysokie, osiągając $101 / 2$ rubla za $1 \mathrm{~m}^{2}$ nawierzchni, wycenionej łącznie $z$ betonową podbudową lub $81 / 2$ rubla za $1 \mathrm{~m}^{2}$ samej nawierzchni. Wykonane nawierzchnie asfaltowe użytkowano przez okres gwarancji, w którym pojawiające się spękania asfaltu mieli obowiązek naprawiać przedsiębiorcy. Gdy po upływie gwarancji asfalt popękał, podjęto decyzję o jego usunięciu ze względu na brak miejskiego sprzętu do napraw ${ }^{41}$. Notatka w „Kurjerze Warszawskim” z dnia 15 kwietnia 1897 r., w której czytamy, że „Przy zbiegu ulicy Królewskiej i placu Saskiego firma Valentino zdziera bruk asfaltowy, ułożony w/r. z. i ustawiła szereg pieców w celu ułożenia bruku nowego"42, ujawnia fakt podjęcia kolejnej próby.

Wobec niepowodzeń w stosowaniu nawierzchni bitumicznych, większość przebudowywanych ulic brukowano kostką drewnianą i „w ten sposób doszło miasto w r. 1901 do posiadania około $180000 \mathrm{~m}^{2}$ bruku drewnianego, który jednak od początku swego istnienia gruntownie nie był remontowany". Na remonty nawierzchni z kostki drewnianej przeznaczano wówczas 70000 rubli rocznie. Tartak uruchomiony przez wydział budowlany magistratu, produkował kostkę brukową (4-, 5- i 6-calową, z drewna sosnowego nasyconego siarczanem miedzi) ${ }^{43} \mathrm{w}$ ilości od 20 do 30 tys. $\mathrm{m}^{2}$ rocznie ${ }^{44}$. Przy przebudowie nawierzchni stosowano również inne gatunki drewna, na co wskazuje informacja z 1901 r. zamieszczona w „Kurjerze Warszawskim”, że od 3 sierpnia będzie zamknięta

37 „Kurjer Warszawski” r. 77, 1897, nr 257 Dodatek poranny, s. 1, także: Roboty miejskie w Warszawie, „Przegląd Techniczny" r. 4, 1878, t. 7, s. 180.

38 „Kurjer Warszawski” r. 78, 1898, nr 312, s. 4.

39 „Kurjer Warszawski" r. 74, 1894, nr 106 Dodatek poranny, s. 1.

40 Przed 1891 r. w Warszawie były podejmowane nieudane próby utwardzania asfaltem lanym ulic Chmielnej, Kanonii i Rycerskiej, Z. Sznuk, op. cit., s. 215. W tym samym okresie w Berlinie przeważały nawierzchnie z asfaltu prasowanego, natomiast w Paryżu i w Londynie nawierzchnie z kostki drewnianej, Z. Sznuk, op. cit., nr 29-30, s. 255.

41 Ibid., s. 256; nr 33-34, s. 289. Wg informacji inż. Z. Sznuka asfalt San-Valentino zawierał $10 \%$ bitumu i $80 \%$ wapienia, a asfalt Limer $11 \%$ bitumu i $70 \%$ wapienia.

42 „Kurjer Warszawski” r. 81, 1897, nr 105 Dodatek poranny, s. 1.

43 H. Janczewski, Warszawa. Geneza i rozwój inżynierii miejskiej, Warszawa 1971, s. 205.

44 Z. Sznuk, op. cit., nr 25-26, s. 216. 
„Ul. Wierzbowa od ul. hr. Kotzebuego do Niecałej, z powodu układania bruku z dębu australskiego" 45 . Już rok wcześniej bruki z australijskiego drewna zastosowano na innym fragmencie ul. Wierzbowej, na placu Saskim i na Nowym Świecie ${ }^{46}$. Znacznie później, w 1909 r., inżynier Sznuk oferował miastu ułożenie bruku z drewna quebracho ${ }^{47}$ z Ameryki Południowej.

W początkach XX w. w Warszawie podejmowano próby zastosowania także i innych rodzajów nawierzchni ulic. W 1902 r. wydział budowlany magistratu zlecił firmie inżyniera Sznuka ułożenie na ul. Rymarskiej bruku z budapesztańskiego klinkieru, a następnie na placu Zielonym (obecnym placu Jana Henryka Dąbrowskiego), z materiału polskiego, produkowanego przez fabrykę klinkieru w Wierzbniku. Wysokie cła nałożone przez władze Imperium Rosyjskiego na import klinkieru, a potem bankructwo polskiej fabryki w Wierzbniku uniemożliwiły upowszechnienie tej technologii ${ }^{48}$. Warszawskie ulice, po których odbywał się ruch ciężki, brukowano kostką granitową sprowadzaną z Finlandii i z Podola ${ }^{49}$.

Z roku na rok wzrastał zakres ulepszania nawierzchni warszawskich ulic. W 1905 r. na budowę wszystkich rodzajów nawierzchni wydatkowano 471550 rubli, a na ich remonty 331600 rubli. W efekcie wykonanych robót powierzchnia bruków drewnianych osiągnęła $276000 \mathrm{~m}^{2}$, lecz na ich remonty wydatkowano zaledwie 106065 rubli $^{50}$. Bruki drewniane były równe, ciche i bezpieczne dla koni, jednak pod warunkiem przeznaczania adekwatnych środków finansowych na wykonywanie prac konserwacyjnych, robót utrzymaniowych i remontów.

Cytowane liczby ujawniają, że w latach 1894-1905 w Warszawie, kwoty wydatkowane na utrzymanie i remonty wszystkich bruków drewnianych w proporcji do wartości ich odtworzenia malały, co musiało wpływać na pogarszanie się stanu technicznego tych nawierzchni. Zostało to zauważone przez mieszkańców i spotykało się z kolejną krytyką warszawskiej prasy. Niezadowolenie wzrosło do tego stopnia, że generał-gubernator warszawski Gieorgij Skałon (1847-1914) zdecydował o podjęciu formalnych czynności wyjaśniających. 19 czerwca 1909 r. została utworzona „wielka komisya brukowa, w której skład weszli poza funkcyonaryuszami magistrackimi, obywatele, profesorowie politechniki, inżynierowie kolei, urzędu gubernialnego, przedsiębiorcy robót i t. p.". W 1910 r. wielka komisja brukowa, której wówczas przewodniczył Aleksander Miller (1862-1923), pełniący obowiązki prezydenta miasta Warszawy uznała, „że nie zła robota, lecz nietrafny typ jest przyczyną złego stanu bruków, że należy zaprzestać wprowadzania drzewa na ulicach głównych" ${ }^{51}$. Tym samym, diametralnie zmieniono zasady brukowania ulic, wprowadzone przez inżyniera Mościckiego i stosowane od $1893 \mathrm{r}^{52}$

„Kurjer Warszawski” r. 81, 1901, nr 216, s. 3.

46 H. Janczewski, op. cit.

47 „Kurjer Warszawski” r. 89, 1909, nr 181 Dodatek poranny, s. 1. W językach portugalskim i hiszpańskim quebrado oznacza złamany, a nazwa drewna najprawdopodobniej powstała wskutek łamania siekier przez drwali.

48 Z. Sznuk, op. cit., nr 33-34, s. 290.

49 L. Belmont, op. cit., s. 27.

50 Z. Sznuk, op. cit., $\mathrm{nr} 25-26$, s. 216.

51 Z. Sznuk, op. cit., nr 29-30, s. 254. Także: H. Janczewski, op. cit., s. 205. Aleksander Miller był Rosjaninem, który od 4 IX 1909 r. do 4 VIII 1915 r. pełnił obowiązki prezydenta miasta Warszawy.

52 Od 1911 r. rozpoczęto stosowanie w Warszawie bruku drobnokostkowego (8-10 cm grubości) z bazaltu, granitu szwedzkiego lub sporadycznie granitu gniewańskiego. Do 1917 r. zabrukowano w ten sposób 90000 m² $^{2}$ ulic. Za: A. Przybylski, O zastosowaniu bruku drobnokostkowego na drogach podmiejskich, „Przegląd Technicz ny" r. 43, 1917, nr 21-22, s. 177; nr 25-26, s. 220. 
Podobnych emocji przysporzył inżynierowi Mościckiemu udział w przygotowaniach do budowy warszawskiej elektrowni. W celu wymiany miejskiego oświetlenia, z gazowego na elektryczne, w 1895 r. wydział budowlany magistratu opracował pod jego kierownictwem projekt budowy dwóch elektrowni. W 1896 r. projekt został zatwierdzony przez władze Imperium Rosyjskiego. Na podstawie zatwierdzonego projektu miała zostać udzielona koncesja na okres 35 lat z prawem wykupu elektrowni przez miasto po pięciu latach jej użytkowania. Koncesji tej nie udzielono, ponieważ William Heerlein Lindley opracował konkurencyjny projekt elektrowni o mocy 4000 kW (z możliwością rozbudowy do 11000 kW), zlokalizowanej przy ul. Dobrej oraz zaproponował jej budowę i użytkowanie w systemie gospodarczym przez władze miasta. Prezydent miasta Warszawy podjął decyzję o sfinansowaniu projektu Lindley'a, co wywołało protesty i publiczną krytykę ${ }^{53}$. Zaangażował się w nią Aleksander Głowacki (Bolesław Prus). W prowadzonej przez niego kronice tygodniowej czytamy:

P. Mościcki chce, ażeby wprowadzeniem elektryczności do nas zajęła się jakaś firma, która już posiada specyalne wykształcenie, specyalnych ludzi, specyalne laboratorya, narzędzia i machiny, firma, która nic innego nie robi, tylko - zaprowadza elektryczność wedle najlepszych wskazówek. Zaś p. Lindley chce fabrykantem elektryczności zrobić... miasto, w którem nietylko jeszcze elektryczność należy do dziwowisk, ale które nie mogło zdobyć się na własne tramwaye, nie może zdobyć się na porządne bruki ani na... ludowe łazienki!... ${ }^{54}$

Ostatecznie została zrealizowana koncepcja Lindley'a, jednak w przeforsowanym przez Mościckiego trybie koncesji, której beneficjentem do 1915 r. było Warszawskie Towarzystwo Elektryczne. Dzięki zbudowaniu elektrowni przy ul. Dobrej, a potem elektrowni tramwajowej, od 7 lutego 1908 r. warszawskie tramwaje konne kursujące na poszczególnych liniach mogły być zastępowane przez tramwaje elektryczne ${ }^{55}$. Do 1 lipca 1910 r., pod przewodnictwem prezydenta miasta Warszawy, miał prowadzić działalność komitet budowy tramwajów, którego członkiem był starszy inżynier Mościcki ${ }^{56}$.

Niezależnie od służbowych obowiązków inż. Mościcki nadal interesował się mechaniką i elektrotechniką oraz opracowywał projekty, które patentował w kraju i zagranicą. Przykładem tej działalności jest jego patent z 1895 r. na mechanizm rozrządu do silników, opublikowany w Dzienniku Urzędowym Urzędu Patentowego Stanów Zjednoczonych $^{57}$ (Ryc. 4).

Z inicjatywy doktora Stanisława Markiewicza (1839-1911), prekursora działań na rzecz polskiej higieny i zdrowia publicznego, wspieranej publikacjami Aleksandra Głowackiego (Bolesława Prusa) i za zgodą władz Imperium Rosyjskiego, w 1898 r. powstało Warszawskie Towarzystwo Higieniczne. Na jego pierwszym posiedzeniu organizacyjnym w dniu 1 czerwca powołano 12-osobową Radę Zarządzającą, w skład której weszli zarów-

53 R. Żelichowski, P. E. Weszpiński, William Heerlein Lindley. Plan Warszawy, Warszawa 2016, s. 74-76.

54 B. Prus, Kronika tygodniowa, „Kuryer Codzienny” r. 33, 1897, nr 101, s. 2.

55 D. Walczak, Warszawskie tramwaje konne 1866-1908, [b.m.w.] 2016, s. 267.

56 „Kurjer Warszawski” r. 89, 1909, nr 153 Dodatek poranny, s. 2.

57 Patent No. 546,770, Kajetan Mościcki (Warsaw, Russia), „Official Gazette of the United States Patent Office” 1895, 24 IX 1895. 
no inicjatorzy powstania towarzystwa, jak i inżynierowie Alfons Grotowski i Kajetan Mościcki ${ }^{58}$. Ich wybór nie był przypadkowy, ponieważ prowadzili działalność zawodową obejmującą budowę wodociągów, kanalizacji, nawierzchni dróg i chodników, poprawiającą warunki sanitarne panujące w Warszawie, zmniejszając prawdopodobieństwo wybuchu epidemii. Zły stan sanitarny miasta powodował wysoką śmiertelność (w latach 1877-1888 według Ciemniewskiego - 30,49 przypadków śmiertelnych rocznie na 1000 mieszkańców) ${ }^{59}$ i stwarzał potrzebę podnoszenia świadomości i wiedzy społeczeństwa na temat higieny i zdrowego stylu życia. W tym celu pod koniec XIX w. odbyły się w Warszawie dwie wystawy higieniczne; pierwsza w 1887 r. na niezabudowanych terenach u zbiegu ul. Pięknej i Alej Ujazdowskich, druga w 1896 r. - na placu pomiędzy ulicami Polną, Kaliksta i Nowowiejską.

Kajetan Mościcki był wiceprezesem komitetu organizacyjnego Drugiej Wysta-

Cieim.-1, A ootroller for alesm aod other eagnaen, compriaing - gear wbeel mounted on the maia dririog ahah, two ecceotric gear whela meabing with the gear whed oo the driviag abah, a lever rotatiog on the driving aban and carryiag the two ecosetric gear wheek - valve rod necered eccentrically to said ecosetric gear wheeb and driven thereby to operato and reciprocate a valre, enbutatially an and for the parpoess eet fortb.

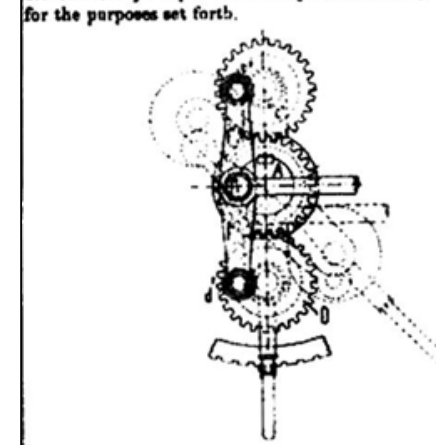

2. A controber for steam and other eagioen compriaiog a gear wheel movolod os the mala driving abah, two ecesetric gear wbeele meabing with tho gear wheel of tho driviag abah, a lever rotatiog oo the driviagh ahan aod carrgiag the eccoatrie gear wbeols a tink piroved cocentrically to both ecceotric gear wheelo and a ralvo rod jourakled to the middlo of mid liok, sabtantially an apd for the porposeanes forth. wy Higienicznej. „Tygodnik Illustrowany” poświęcił tej wystawie obszerny artykuł, z którego dowiadujemy się, że wskazanie jej lokalizacji „to pierwsza zdobycz, a jednocześnie i pierwsza pomoc, jaką wystawa za wstawiennictwem inżyniera miasta, p. Mościckiego, otrzymała ze strony życzliwego dla sprawy pożytecznej p. Prezydenta miasta"60. W miejscu, gdzie odbyła się Pierwsza Wystawa Higieniczna urządzono park Ujazdowski, który 10 sierpnia 1896 r. otworzył inicjator jego powstania, rosyjski generał Mikołaj Walerianowicz Bibikow (1842-1923), pełniący obowiązki prezydenta Warszawy. Podczas uroczystości prezydentowi towarzyszyło 11 osób, zasłużonych dla tego przedsięwzięcia, wśród których znaleźli się projektant parku Franciszek Szanior (1853-1945) oraz inżynierowie Lindley i Mościcki61.

Od 1897 r. w życiu prywatnym 42-letniego Kajetana Kazimierza Mościckiego następowały ważne wydarzenia. Wówczas w parafii św. Antoniego w Warszawie odbył się jego ślub z Janiną Anną Lucyną Rychter, urodzoną w 1878 r. W następnym roku przyszedł na świat ich syn Bohdan Kajetan, a w 1900 r. córka Lucyna Janina. 5 listopada 1900 r., zaledwie trzy lata po ślubie, 22-letnia Janina Mościcka z Rychterów zmarła62.

K. Dragański, J. Żbikowski, Spotkania z historią Polskiego Towarzystwa Higienicznego/Encounters with the history of the Polish Society of Hygiene - Dr. Stanisław Markiewicz, "Hygeia Public Health" 2011, 46(4), s. 503.

59 R. Żelichowski, Lindleyowie. Dzieje inżynierskiego rodu, Warszawa 2002, s. 401.

60 II-ga Wystawa Hygieniczna w Warszawie przed otwarciem, „Tygodnik Illustrowany” r. 37, 1896, nr 18, s. 345.

61 „Kurjer Warszawski” r. 76, 1896, nr 221 Dodatek poranny, s. 1-2.

62 M.J. Minakowski, op. cit. 


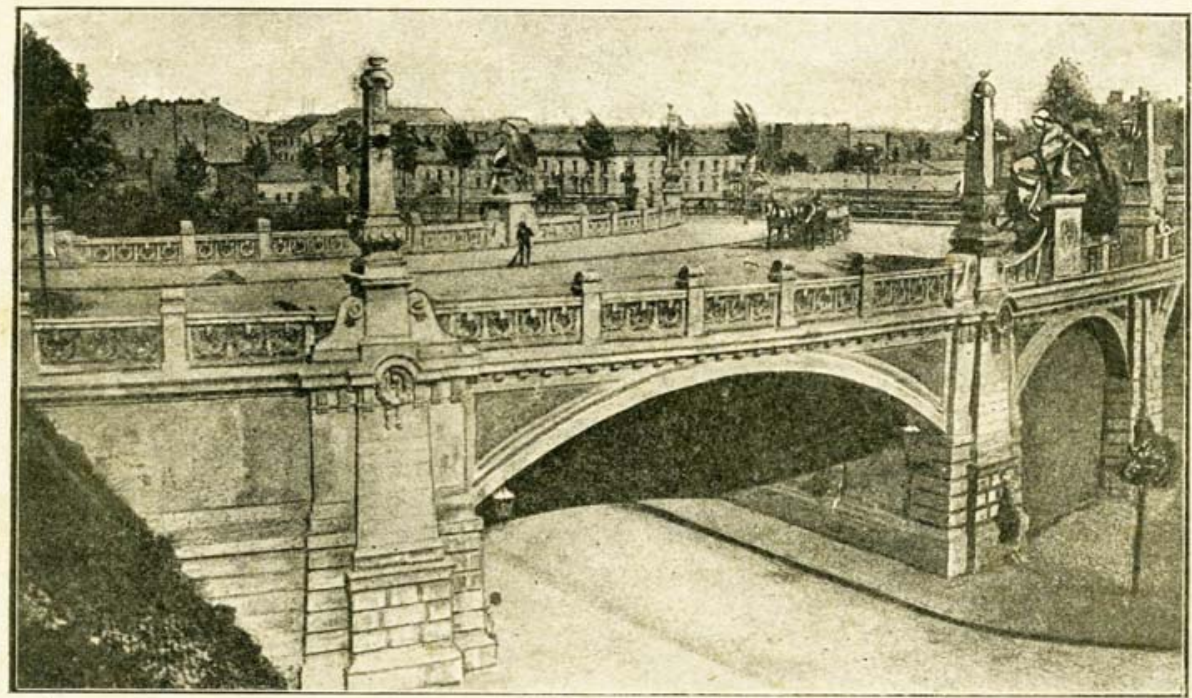

ВАРШАВА, Каровая ул.

WARSZAWA, ul. Karowa.

WARSCHAU, Karowa-Str.

Ryc. 5. Wiadukt na ul. Karowej na pocztówce ze stemplem pocztowym 25 maja 1915 r. (ze zbiorów autora).

Przy podejmowaniu decyzji dotyczących rozbudowy infrastruktury transportowej miasta Warszawy starszy inżynier Kajetan Mościcki wykazywał skłonność do wspierania innowacji. Zapewne dzięki temu przymiotowi jego charakteru, około 5 sierpnia 1897 r., magistrat warszawski zrezygnował z budowy drewnianego mostu w parku Ujazdowskim i udzielił Biuru Technicznemu Arnold Bronikowski \& S-ka Inżynierowie zlecenia na zaprojektowanie i zbudowanie najprawdopodobniej pierwszego w Królestwie Polskim mostu z betonu uzbrojonego (żelbetu), o konstrukcji łukowej, według patentu Josepha Moniera (1823-1906). Zlokalizowany nad parkowym stawem jednoprzęsłowy most o rozpiętości 6 metrów został ukończony około 20 maja 1898 r. ${ }^{63}$

Kolejnym, nadzorowanym przez inżyniera Mościckiego, lecz już znacznie większym drogowym obiektem inżynierskim z żelbetu był wiadukt, o dwóch przęsłach o rozpiętościach 12,84 m i 13,16 m, zlokalizowany w ciągu ulicy Karowej w Warszawie w łuku tzw. ślimaka o promieniu 45 m (Ryc. 5). Został zaprojektowany w latach 1900-1902, następnie zbudowany i 11 grudnia 1904 r. oddany do użytku przez wspomnianą wyżej firmę inż. Arnolda Bronikowskiego (1846-1907) ${ }^{64}$.

"Tygodnik Illustrowany" jako pierwszy, opublikował w grudniu 1895 r. informację na temat planowanej budowy zjazdu z ulicy Karowej na warszawskie Powiśle. W jednostronicowym artykule zamieszczono perspektywiczny rysunek ulicy i przekazano następujące informacje: „Z rozporządzenia naczelnego inżyniera miasta, p. Mościckiego, przeprowa-

63 M. Mistewicz, Pierwsze w Królestwie Polskim mosty systemu Moniera zbudowane przez inżyniera Arnolda Bronikowskiego, „Kwartalnik Historii Nauki i Techniki” t. 64, 2019, nr 1, s. 43-45.

64 Ibid., s. 49-52. Wiaduktowi w ciągu ul. Karowej nadano imię Stanisława Markiewicza. 


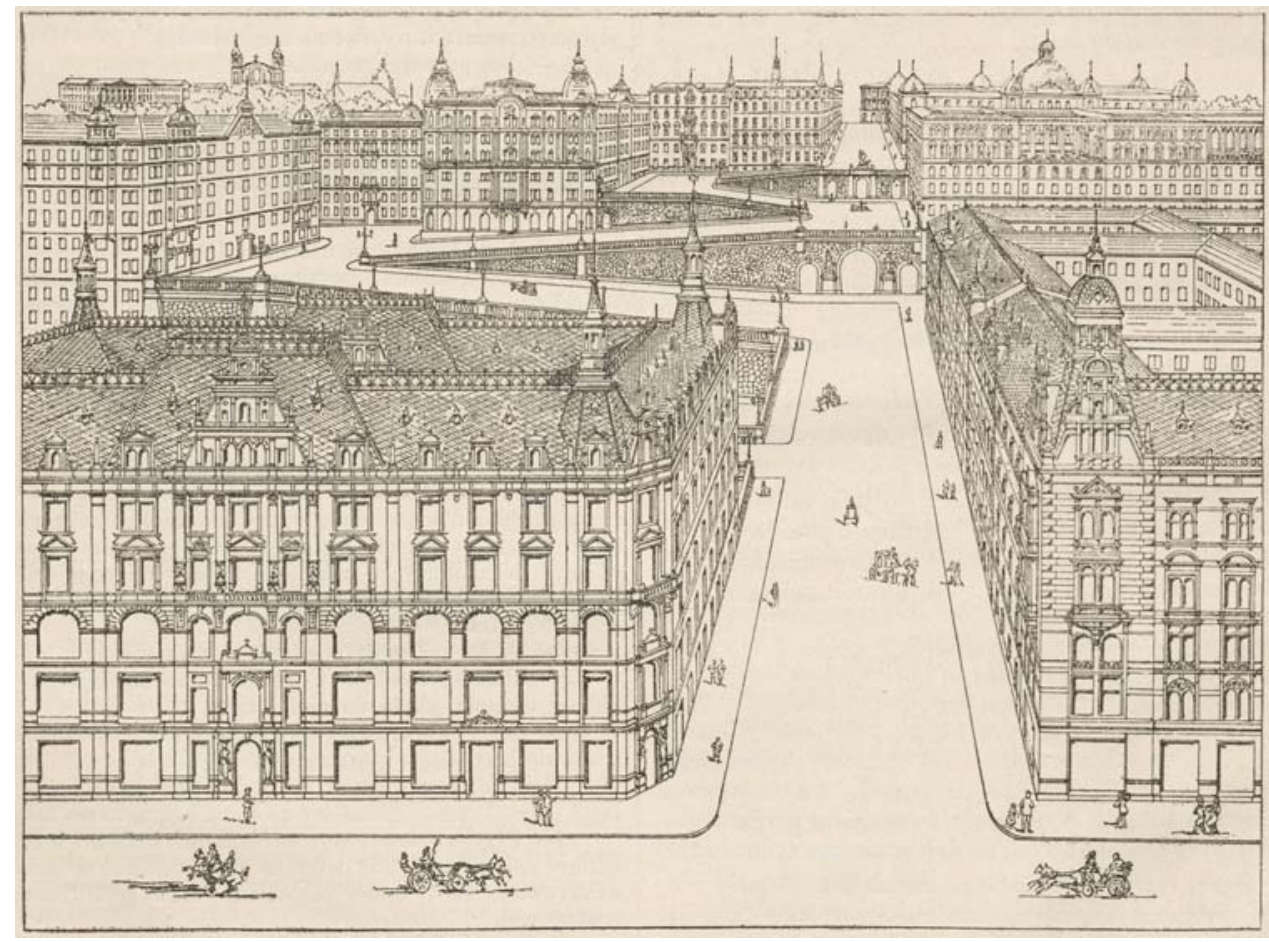

Ryc. 6. Projekt nowej dzielnicy przy ul. Karowej opracowany przez Rudnickiego i Kozłowskiego, opublikowany w „Tygodniku Illustrowanym” z 1895 r. (Mazowiecka Biblioteka Cyfrowa).

dzono niwelacyę przyległych terenów i na tej podstawie biuro wydziału sporządziło projekt, opracowany przez inż. Rudnickiego i budow. Wł. Kozłowskiego"65. Na rysunku załączonym do artykułu widzimy dwustopniowy zjazd ze skarpy, ukształtowany w formie pary ostro zakręcających serpentyn, z dwoma trójprzęsłowymi wiaduktami (Ryc. 6). Dalej czytamy, że „Projekt, przedyskutowany i przyjęty w zasadzie na posiedzeniu rady magistratu, uzyskał aprobatę J. W. Prezydenta miasta i po rozpatrzeniu powtórnem przez delegowaną specyalnie w tym celu komisyę, będzie złożony do zatwierdzenia władzy wyższej"66. Ten sam rysunek ul. Karowej zamieściło w lipcu 1896 r. pismo literacko-polityczne ilustrowane „Biesiada Literacka"67. Wydział budowlany magistratu prowadził wówczas negocjacje w sprawie wykupu terenu pod inwestycję. $Z$ instytucjami publicznymi uzyskał konsensus, „Ze strony zaś właścicieli, którzy z tej regulacyi największą mogliby wyciągnąć korzyść, magistrat nie znalazł żadnego współdziałania, ale obok tego, rozpoczęta została agitacya w prasie, przeciwko projektowi, widocznie w celu uzyskania pozornej podstawy do stawienia nadmiernych żądań"68. Wobec napotkanych trudności z pozyskaniem gruntu, prace studialne nad ukształtowaniem zjazdu z wysokiej skarpy na projektowane wiślane bulwary musiały być kontynuowane. 


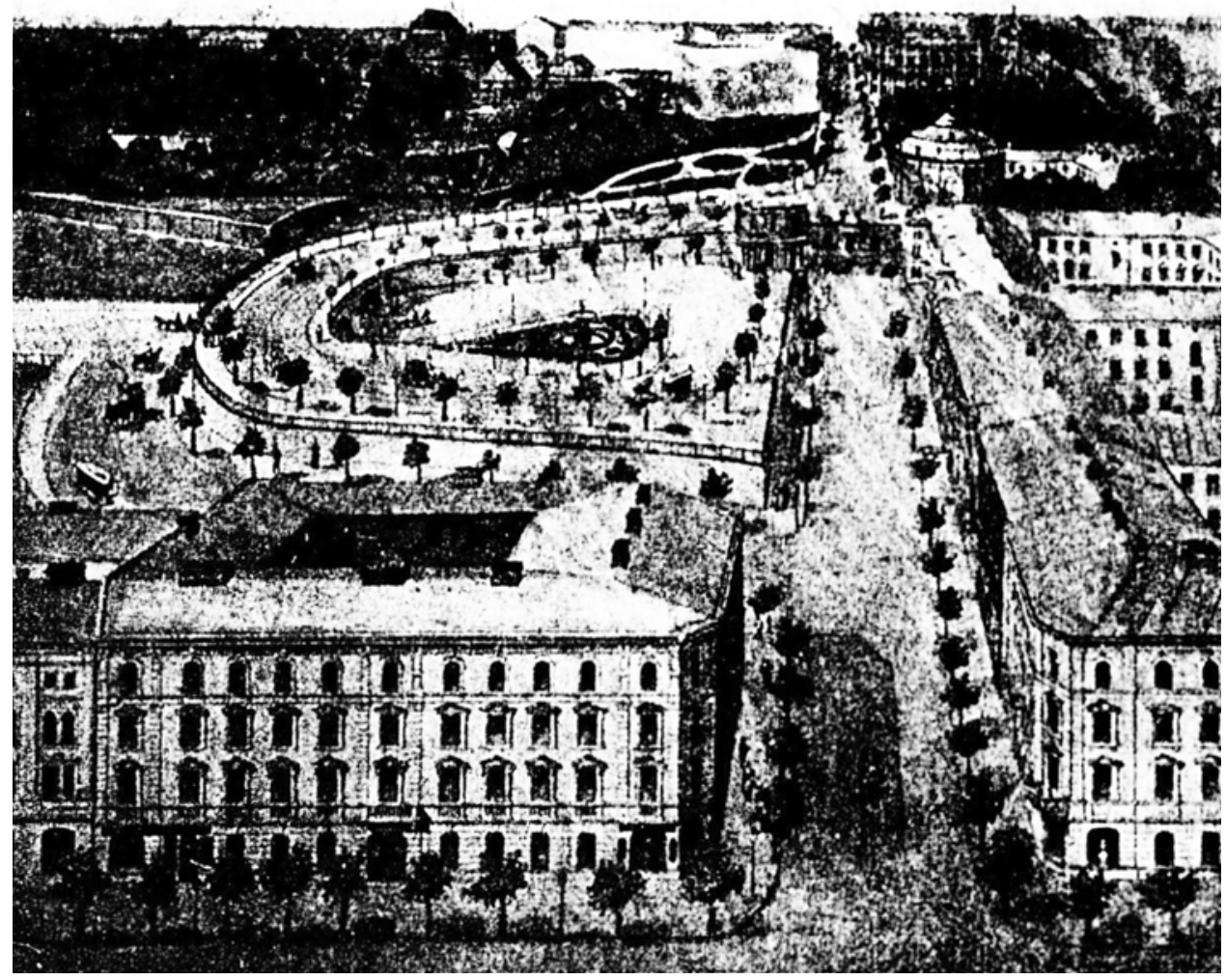

Ryc. 7. Rysunek tzw. ślimaka na ul. Karowej opublikowany w piśmie „Wędrowiec” w 1900 r. (polona.pl).

Pod kierunkiem inżyniera Mościckiego, od 1897 r. wydział budowlany magistratu pracował nad kolejną koncepcją urbanistyczną zjazdu z ulicy Karowej, w formie tzw. ślimaka. W sierpniu 1900 r. redaktor Władysław Koleżak (1854-1924) pokazał to rozwiązanie czytelnikom, na perspektywicznym rysunku zamieszczonym w piśmie „Wędrowiec” (Ryc. 7). W opublikowanym tam artykule czytamy również, że:

Na pocieszenie mieszkańców Powiśla notujemy, iż budowa zjazdu na ulicy Karowej, zacznie się już w r. b. Na początek wyasygnował magistrat sumę rs. [rubli srebrnych - M.M.] 15,000. Roboty powierzono inżynierowi miasta p. Kazimierzowi Dankowskiemu. W tych dniach ogłoszoną zostanie licytacya na to przedsiębiorstwo w zakresie sumy wymienioneje ${ }^{69}$.

Zgodnie z zapowiedzią, w 1900 r. rozpoczęto przebudowę ulicy Karowej od strony Krakowskiego Przedmieścia na długości 90 sążni [192,02 m - M.M.]. Na jezdni układano kostkę z granitu szwedzkiego na podbudowie piaskowej, a na betonowych chodnikach - 


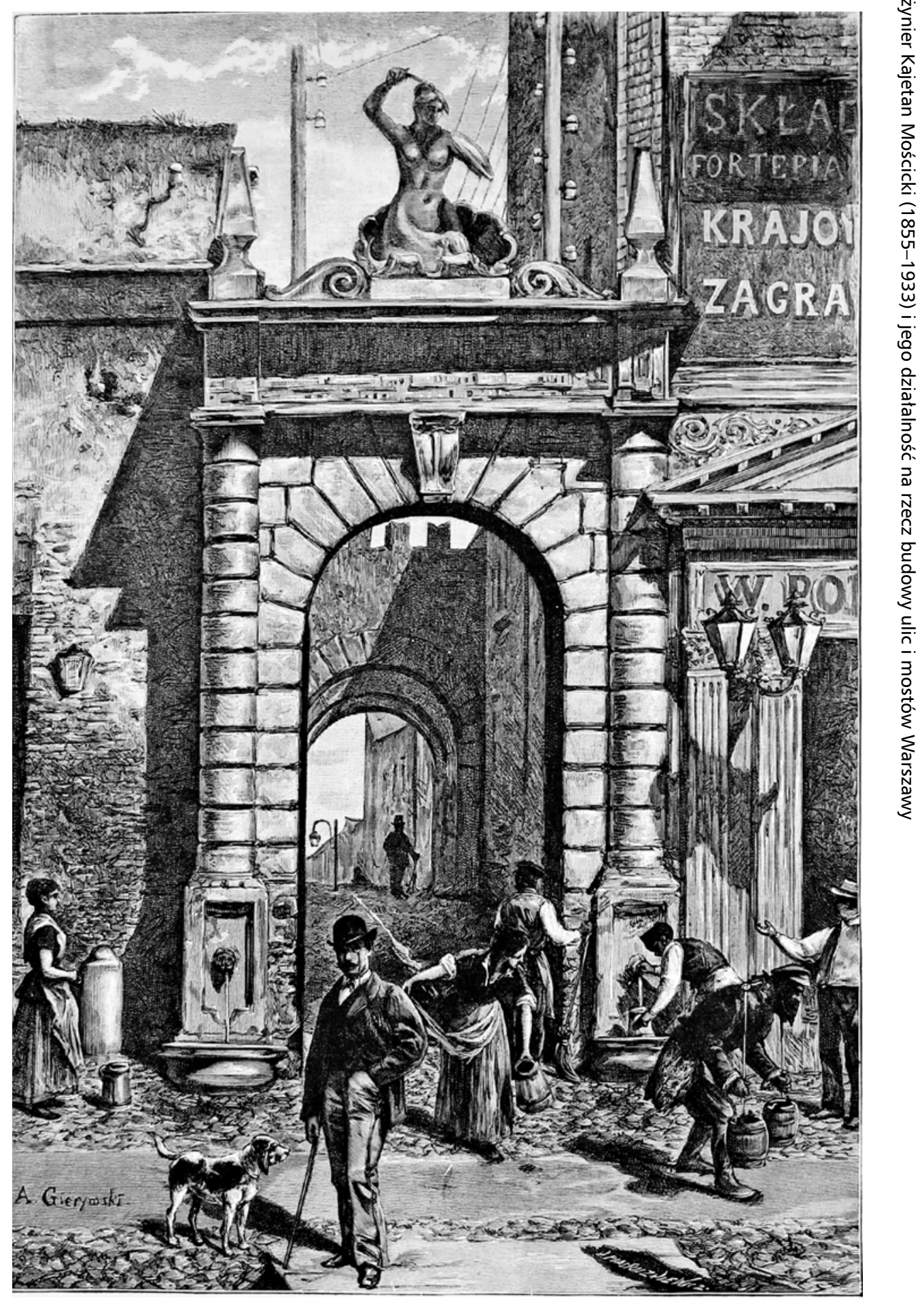

Ryc. 8. Brama przy zbiegu Krakowskiego Przedmieścia i ul. Karowej na rysunku Aleksandra Gierymskiego zamieszczonym w „Tygodniku Powszechnym" z 1883 r., rycina Kazimierza Pastuszkiewicza, fot. Andrzej Marecki (ze zbiorów autora). 
zapewne prefabrykowane płyty. „W miejscu tem, szerokość ulicy liczyć będzie 81/2 sążnia [18,14 m - M.M.], a później rozszerzona być ma do 10 sążni [21,34 m - M.M.], kosztem posesyi narożnej, należącej do p. Salomona Lewentala"70. W celu poszerzenia ulicy zburzono piękną bramę stojącą na wjeździe w ulicę Karową z Krakowskiego Przedmieścia. Budowla ta, z ozdobnym nadprożem zwieńczonym herbem Warszawy - Syreną - została zaprojektowana w 1855 r. przez urodzonego we Włoszech, a następnie spolonizowanego architekta Henryka Marconiego (1792-1863). Na obu filarach mieściła czerpnie wody miejskiej w rzeźbiarskiej oprawie paszcz lwów, górujących nad owalnymi misami. Jej widok pokazał malarz Aleksander Gierymski (1850-1901) na jednym ze swoich rysunków ${ }^{71}$ (Ryc. 8).

We wspomnianym artykule redaktor Koleżak przedstawił w sposób obrazowy plany rzeczowe warszawskiego magistratu, odnoszące się do budowy tzw. ślimaka w ciągu ul. Karowej w 1901 r. i w latach następnych:

W roku przyszłym budowa tego zjazdu prowadzoną będzie w dalszym ciągu, nie w prostej linii ulicy Karowej, lecz w prawo skieruje się nasyp do ogrodu nabytego na terytorium posesyi byłego klasztoru PP. Wizytek, zakreśli koło z małym spadkiem (nie większym niż posiada zjazd Pancera), wracając ku ulicy Karowej, a ztąd znowu skręca z powrotem i prowadzi w kierunku dwóch wiaduktów o 6-cio-sążniowych otworach, przecinających w środku półkole nasypu. [...] Długość nasypu, którego wysokość od skrętu w ogród po-wizytkowski sięgać będzie 21/2 piętra, liczy 250 sążeniów [533,39 m-M.M. $]^{72}$.

Nakłady finansowe zaplanowane na przebudowę ul. Karowej wynosiły 315000 rubli. Do prowadzenia robót ziemnych, niezbędne były projekty wykonawcze z przedmiarami, które pod nadzorem naczelnika Mościckiego wykonywał miejski inżynier Kazimierz Dankowski, kierujący przebudową ul. Karowej³ (Ryc. 9).

Oddany do użytku pod koniec 1904 r. zjazd z ul. Karowej był na owe czasy budowlą bardzo oryginalną, wzbudzającą powszechne zainteresowanie. W piśmie "Życie i Sztuka" porównano go wówczas do podobnych rozwiązań stosowanych w innych dziedzinach techniki:

Jest to więc rodzaj spirali, czy śruby, używany dość często we współczesnej technice sposób, między innemi zastosowany i do tunelu św. Gotharda, gdzie pociągi również czynią koło po spadku, aby wyjść na poziom znacznie wyższy. Gdzie prze-

70 Ibid. Salomon (Franciszek Salezy) Lewental (1839 lub1841-1902) był księgarzem warszawskim, redaktorem tygodnika "Kłosy”, wydawcą m.in. dzieł: Aleksandra Fredry, Władysława Syrokomli, Elizy Orzeszkowej, Józefa Ignacego Kraszewskiego, Józefa Korzeniowskiego, wielkoformatowego Albumu Jana Matejki oraz współwłaścicielem „Kurjera Warszawskiego”.

71 A. Gierymski, Wodociąg przy zbiegu Krak.-Przedmieścia i ul. Karowej, „Tygodnik Powszechny” r. 7, 1883, nr 21, s. 329. Aleksander Gierymski był młodszym bratem malarza Maksymiliana Gierymskiego, absolwentem Akademii Sztuk Pięknych w Monachium, przedstawicielem tzw. realizmu i prekursorem polskiego impresjonizmu. Wykonywał ilustracje do tygodnika „Kłosy” i „Tygodnika Illustrowanego”. Namalował m.in. znane obrazy: Żydówka z pomarańczami 1881, W altanie 1882, Święto trąbek I 1884, Szewczyk warszawski 1885, Piaskarze 1887, Trumna chłopska 1894 i Morze 1897, przechowywane w Muzeum Narodowym w Warszawie.

72 W. Koleżak, op. cit.

73 M. Kałamajska-Saeed, Wiadukt ulicy Karowej w Warszawie, „Kwartalnik Architektury i Urbanistyki” r. 22, 1977, nr 2, s. 149-160. 


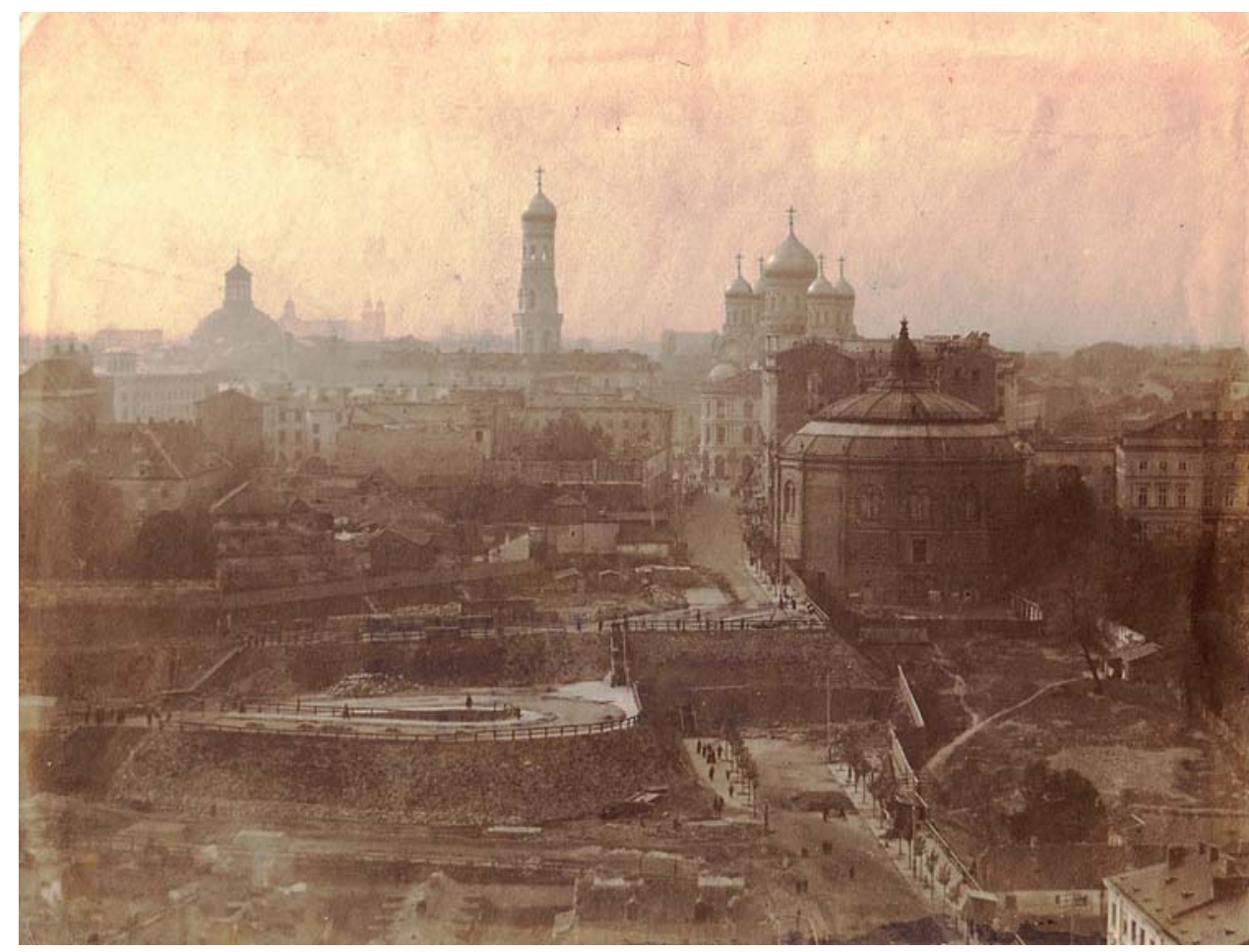

Ryc. 9. Budowa tzw. ślimaka w ciągu ul. Karowej w Warszawie, a w jej tle widoczny sobór na placu Saskim, na fotografii z ok. 1904 r., autor nieznany (otwarty dostęp: scontent-frt3-1.xx.fbcdn.net).

strzeń jest mała, a spadek duży, taki „ślimak” rozwiązuje trudne zadanie komunikacyjne najprościej i najpraktyczniej ${ }^{74}$.

Dwukierunkowy "ślimak" pełnił funkcję łącznicy wyjazdowej i wjazdowej dla dwóch poziomów ulicy Karowej, rozdzielonych wysoką wiślaną skarpą (Ryc. 10). W dziedzinie organizacji ruchu drogowego był innowacyjnym rozwiązaniem technicznym, zastosowanym w Królestwie Polskim po raz pierwszy. W przyszłości, po zbudowaniu w ciągu ulicy Karowej estakady prowadzącej na most przez Wisłę, mógłby z jego wykorzystaniem powstać pierwszy w Warszawie nowoczesny węzeł drogowy zapewniający pełną możliwość wyboru kierunku jazdy ${ }^{75}$. Tym samym, przyjęte i zrealizowane rozwiązanie projektowe jest świadectwem wiedzy i dalekowzroczności inżynierów Polaków z przełomu XIX i XX w.

Podział Warszawy po linii Wisły, przy niewystarczającym skomunikowaniu dzielnic lewobrzeżnych z prawobrzeżną Pragą po jedynym miejskim Moście Aleksandrowskim (drogowo-tramwajowym) stwarzał utrudnienia $\mathrm{w}$ cywilnym transporcie kołowym ${ }^{76}$. 13 czerwca 1903 r. Warszawa uzyskała pożyczkę w kwocie 33000000 rubli z zagranicz-

74 Ślimak warszawski, „Życie i Sztuka. Pismo dodatkowe, ilustrowane. Kraj” 1904, nr 46, s. 10-11.

75 Magistrat warszawski w budżecie 1928-1929 przeznaczył 100000 zł na przeprowadzenie przedwstępnych studiów budowy nowego mostu przez Wisłę przy ul. Karowej, za: Most i wiadukt imienia ks. Józefa Poniatowskiego przez rzekę Wisłę w Warszawie [brak autora], Warszawa 1927, s. 144.

76 Po opuszczeniu Warszawy przez Rosjan nazwę zmieniono na most Kierbedzia. 


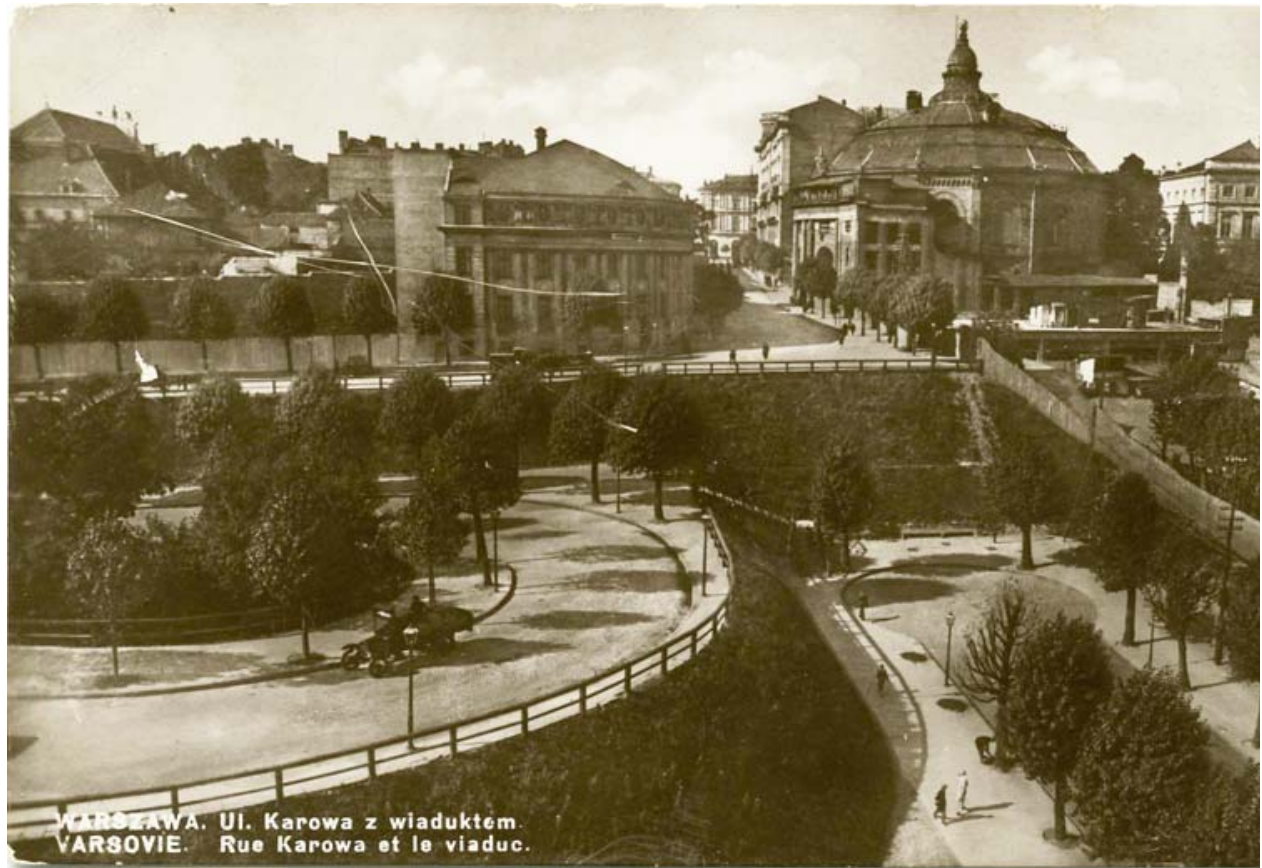

Ryc. 10. Zjazd z ul. Karowej na Powiśle w międzywojniu, na pocztówce nr B16 bez obiegu, po 1926 r. (ze zbiorów autora).

nego Syndykatu Banków, w skład którego wchodził Credit Lyonnais z Paryża77. Dysponując nią, zarząd miejski mógł wyasygnować kwotę 4500000 rubli na planowaną budowę nowego mostu drogowego przez Wisłę ${ }^{78}$. W wydanej w 1927 r. monografii mostu i wiaduktu im. ks. Poniatowskiego czytamy, że

Na wniosek ówczesnego naczelnego inżyniera miasta K. Mościckiego Zarząd miasta postanowił przystąpić do zestawienia przedwstępnego projektu mostu w Alei Jerozolimskiej, polecając opracowanie projektu inżynierowi Mieczysławowi Marszewskiemu, który w tym czasie ukończył był budowę mostu żelaznego przez Narew pod Zegrzem ${ }^{79}$.

W czerwcu 1904 r., pod przewodnictwem prezydenta Bibikowa, powstał 12-osobowy Komitet Budowy Mostu, w którego skład weszli m.in. inżynierowie: Kajetan Mościcki, Ludwik Kurcjusz, Mieczysław Marszewski (1857-1917), Mikołaj Bielelubski (1845-1922), Tadeusz Balicki (1857-1921), Julian Eberhardt (1866-1939), Aleksander Wasiutyński (1859-1944), Edward Natanson (1861-1940) i architekci: K. Pirbudagjan, Stefan Szyller (1857-1933), a potem Władysław Marconi (1848-1915) ${ }^{80}$. Statut i skład tego komitetu został zaaprobowany przez właściwe władze w Petersburgu, a następnie zatwierdzony re-

77 M. Omilianowska, Most i wiadukt księcia Józefa Poniatowskiego, Warszawa 1991, s. 25.

78 J. Jankowski, Pięćdziesięciolecie mostu im. ks. Józefa Poniatowskiego, „Stolica” r. 19, 1964, nr 8, s. 2.

79 Most $i$ wiadukt, s. 15.

80 Ibid. Także: B. Chwaściński, Mosty na Wiśle i ich budowniczowie, Warszawa 1997, s. 98. 
skryptem cesarza, wydanym w $1904 r^{81}$. W tym samym roku, po spełnieniu wymagań postawionych przez rosyjskie Ministerstwo Wojny, zatwierdzono kolejny z kilku wykonanych przez inżyniera Marszewskiego przedwstępnych projektów nowego mostu. 506-metrowy ustrój niosący mostu został zaprojektowany w postaci ośmiu żelaznych przęseł, ukształtowanych $w$ formie parabolicznych łuków dwuprzegubowych z jezdnią górną, o rozpiętościach podawanych od brzegu warszawskiego do praskiego: 32, 58, 68, 80, 68, 58, 58, $38 \mathrm{~m} .{ }^{82}, \mathrm{z}$ jezdnią wybrukowaną kostką drewnianą.

Po rozstrzygnięciu przetargu, budowę tzw. Mostu Trzeciego ${ }^{83}$ powierzono Towarzystwu Akcyjnemu „K. Rudzki i Ska”, które 31 sierpnia 1904 r. rozpoczęło pierwsze prace. Dopiero podczas budowy ujawnili się jej przeciwnicy. Zarzucali magistratowi, że kosztem wydatków na budowę mostu, ponoszonych przez mieszkańców lewobrzeżnej Warszawy, wzrośnie wartość działek należących do właścicieli niezurbanizowanych terenów prawobrzeżnej Saskiej Kępy. Przewidywali także utrudnienia w komunikacji, które dotkną właścicieli fabryk i kamienic czynszowych zbudowanych na warszawskim Powiślu, wskutek zasypania wykopu, którędy zjeżdżano ze skarpy i zbudowania tam wiaduktu prowadzącego wprost na most. W krytykę włączyły się warszawskie dzienniki „Goniec Poranny”, „Nowa Gazeta” i „Kurjer Warszawski”, w którym m.in. napisano, że „nie można się rzeczywiście nadziwić z jaką bezwzględnością traktowane są u nas najżywotniejsze sprawy mieszkańców Warszawy"84. Prace jednak kontynuowano. W 1907 r. rozpoczęto roboty ziemne na lewobrzeżnym dojeździe do mostu, a w 1908 r. budowę fundamentów pod żelbetowy wiadukt o długości $701 \mathrm{~m}$ i pod tzw. wjazd ślimakowy ${ }^{85}$.

W 1909 r. pod przewodnictwem inżyniera Mościckiego obradowała komisja do spraw związanych z budową mostu przez Wisłę, która 27 lipca zadecydowała o rozpisaniu konkursu na projekt zabudowania Saskiej Kępy ${ }^{86}$. Pod koniec roku budowę mostu i wiaduktu przerwano, ponieważ jej koszty okazały się wyższe od zaplanowanych i wystąpiła konieczność zwiększenia nakładów o kwotę 1800000 rubli. Po raz kolejny na magistrat warszawski ruszyła lawina prasowej krytyki ${ }^{87}$.

Zapewne wskutek opisanych wydarzeń do Warszawy przybył z Petersburga senator Dmitrij Neidhardt, który przeprowadził szczegółową rewizję magistrackiego budżetu. $\mathrm{Na}$ jego wniosek, 16 czerwca 1910 r. aresztowano głównego inżyniera budowy mostu Mieczysława Marszewskiego, którego wcześniej Kajetan Mościcki zarekomendował na to stanowisko. Inżynier Marszewski był podejrzany o przywłaszczenie przeznaczonej dla warszawskiego generał-gubernatora Gieorgija Skałona, łapówki w kwocie 100000 rubli, przekazanej przez Towarzystwo Akcyjne „K. Rudzki i Ska”, w zamian za wyrażenie zgody na podpisanie kontraktu na budowę mostu. Pomimo iż inżynierowi Marszewskiemu nie postawiono zarzutów, przebywał w więzieniu na Pawiaku do maja 1911 r. Na stanowisko głównego inżyniera powołano Rosjanina Aleksego Lubickiego, który w 1911 r.

83 Po oddaniu do użytku most nazwano imieniem Mikołaja II, cara Rosji. Zwyczajowo od zbudowania, a oficjalnie po odbudowie ze zniszczeń w pierwszej wojnie światowej most nosi imię księcia Józefa Poniatowskiego. 


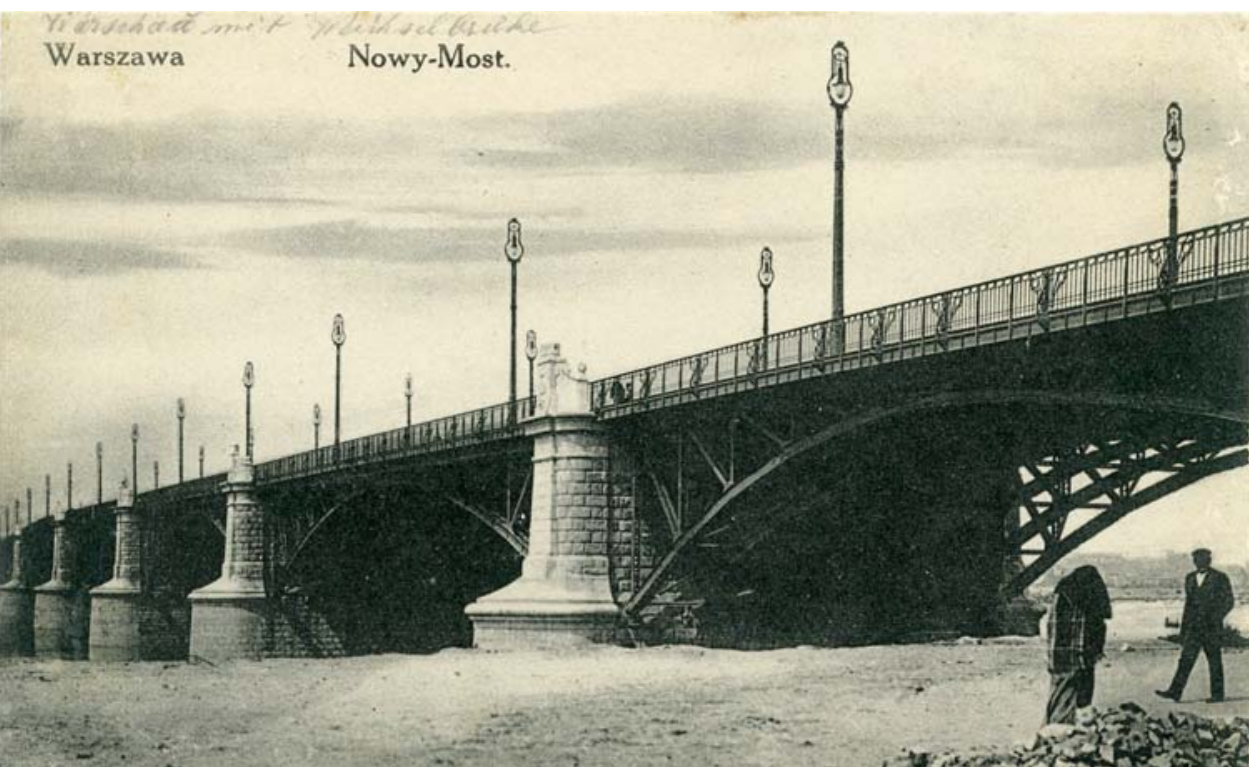

Ryc. 11. Most Trzeci przez Wisłę przed zniszczeniem podczas pierwszej wojny światowej, na pocztówce z treścią datowaną 18 stycznia 1915 r. (ze zbiorów autora).

ukończył budowę mostu ${ }^{88}$ (Ryc. 11). Po latach oskarżyciel Marszewskiego, rosyjski senator Neidhardt wyznał; „Tak jak przypuszczałem, tak też znalazłem, że inżynier Marszewski jest w tej sprawie czysty i niewinny i że padł ofiarą splotu intryg, które się okazały trudnymi do rozwiązania dla rządu"89.

Rok 1909 był dla warszawskich urzędników okresem, w którym permanentnie składali wyjaśnienia kontrolerom, przysyłanym ze stolicy Imperium Rosyjskiego, w związku ze śledztwem w sprawie nadużyć, jakich miał się dopuścić magistrat. Pełniący obowiązki prezydenta miasta Warszawy Wiktor Litwiński kilkakrotnie wyjeżdżał do Petersburga, gdzie 8 lutego tłumaczył się przed premierem i ministrem spraw wewnętrznych Piotrem Stołypinem ${ }^{90}$ (1862-1911), a potem „z powodu choroby na jego prośbę” rozkazem nr 19 z dnia 6 kwietnia 1909 r. odwołano go ze stanowiska ${ }^{91}$. Dopiero 19 czerwca Wiktor Litwiński opuścił na stałe Warszawę̨2, która do 22 września 1909 r. pozostawała z nieobsadzonym urzędem prezydenta. Główny naczelnik kraju rozkazem nr 7564 z dnia 14 kwietnia 1909 r. powołał do czasowego pełnienia tej funkcji Polaka, wiceprezydenta Konstantego Zarembę ${ }^{93}$ (1865-1937).

88 M. Omilianowska, op. cit., s. 76-80.

89 J. Bajkiewicz, Historia budowy Mostu Poniatowskiego i tragedia jego twórcy, „Stolica” r. 14, 1959, nr 23, s. 14-15. Publikacja zawiera relację inż. Jerzego Bajkiewicza, który był uczestnikiem opisywanych wydarzeń, jako współpracownik inż. Mieczysława Marszewskiego podczas budowy mostu.

90 „Kurjer Warszawski” r. 89, 1909, nr 40, s. 1.

91 L. Belmont, op. cit., s. 9.

92 „Kurjer Warszawski” r. 89, 1909, nr 167, s. 7.

93 L. Belmont, op. cit., s. 5-9. Konstanty Zaremba po ukończeniu w 1876 r. sejneńskiej szkoły początkowej (zazwyczaj szkoły te były 1- lub 2-klasowe) pracował w zarządzie powiatowym w Sejnach i w zarządzie gubernialnym w Suwałkach, potem jako sekretarz wydziału policji przy zarządzie powiatowym w Wołkowyszkach, prezydent Radomia i prezydent Lublina. 
Prowizoryczny charakter sprawowanej władzy, przy jednoczesnej zapowiedzi rychłego wprowadzenia miejskiego samorządu, wywoływał zainteresowanie rosyjskich inwestorów, poszukujących okazji. Do takich mógł należeć pan Ignatiew, który złożył ofertę na zbudowanie rzeźni centralnej we Florjanowie, pod warunkiem, że otrzyma koncesję na lat 40 . W celu rozpatrzenia tej oferty powołano komisję specjalną, a jej przewodniczący inż. Mościcki zwołał posiedzenie. „W jakim celu to posiedzenie zwołano, nie wiemy; komu zależy na stworzeniu nowego monopolu i na oddaniu rzeźników na łup spekulantów na długi lat szereg, także nie wiemy; ..." oburzyła się redakcja „Kurjera Warszawskiego" z 19 lipca 1909 r. ${ }^{94}$

Zarzuty nieprawidłowego prowadzenia budowy mostu przez Wisłę i sankcje z tego tytułu nie ominęły pracowników wydziału budowlanego magistratu, którym kierował starszy inżynier miasta Warszawy. Rozkazem nr 93 z dnia 18 maja 1909 r. ze służby w magistracie zostali zwolnieni: młodszy pomocnik starszego inżyniera Ryszard Leon Puciata, rysownik Kazimierz Binder i dyetariusz Cezary Modzelewski ${ }^{95}$. Kajetan Mościcki podjął obronę dwóch z podległych mu pracowników, Bindera i Modzelewskiego, uważając postawione im zarzuty za nieprawdziwe, a karę za niewspółmierną. Z tego powodu stał się osobą niewygodną dla prezydenta Zaremby. Podejrzewał on Mościckiego o inspirowanie krytycznych artykułów prasowych, które wiązały się ze zwolnieniem pracowników oraz zarzucał mu, że podczas ważnej wizyty w Warszawie „Nie wszystkie ulice, któremi przejeżdżał Wielki Książę, były doprowadzone do porządku", że nie sprawował nadzoru nad urzędnikami tartaku miejskiego, zwolnionymi za niedbalstwo już 8 miesięcy wcześniej. Ponadto sprokurowano donos do generał-gubernatora, w którym czytamy, że „P. Mościcki pozwala sobie na posiedzeniach mówić po polsku, nie bacząc na uwagi, czynione mu przez pełn. obow. prezydenta p. Zarembę". Po postawieniu zarzutu „o antyrządowym kierunku jego pracy", rozkazem nr 10 zarządu miejskiego z dnia 31 lipca 1909 r., Kajetana Mościckiego zwolniono ze stanowiska, nie umożliwiając mu wcześniejszego podania się do dymisji i pozbawiając prawa do emerytury ${ }^{96}$. Kurjer Warszawski z dnia 24 sierpnia 1909 r. w dodatku porannym przekazał mieszkańcom Warszawy wiadomość, że „Wczoraj inż. Kajetan Mościcki ostatni raz przyszedł do biura wydziału budowlanego, gdzie serdecznie był żegnany przez swych b. podwładnych"97, a w wydaniu głównym kolejną, że „Obowiązki starszego inżeniera m. Warszawy zlecono tymczasowo jego starszemu pomocnikowi inżenierowi Rudnickiemu"98.

Sposób, w jaki potraktowano Kajetana Mościckiego, spotkał się z dezaprobatą mieszkańców Warszawy. Wyrażał ją Leopold Blumental (1864-1941), warszawski adwokat, prozaik, dramaturg, poeta i wydawca tygodnika społecznego, politycznego, literackiego i naukowego „Wolne Słowo", publikujący artykuły prasowe pod pseudonimem Leo Belmont ${ }^{99}$. Na łamach swojego tygodnika zacytował on następującą treść listu, który do Kajetana Mościckiego napisał były prezydent Warszawy: 
Wielce szanowny i drogi Panie Kajetanie Apolinarowiczu. Niepodobna uwierzyć, że Pańskiej pożytecznej i niestrudzonej działalności położony został kres. Mam nadzieję, że miasto oceni Pańską uczciwą i nieskazitelną służbę i zabezpieczy Pana należycie przy jego ustąpieniu ze stanowiska. Czyżby nie miano przyjąć pod uwagę, że każdy inny na Pańskiem miejscu odszedłby z wielkim majątkiem - gdy Panu pozostały same długi [...]. Jestem pewny, drogi Panie Kajetanie, że takich dobrych ludzi, Jak Pan, nie ominie łaska Boża. Serdecznie Panu oddany N. Bibikow ${ }^{100}$.

Odpierając postawione zarzuty, Kajetan Mościcki odwołał się od rozkazu zwalniającego go ze stanowiska bezpośrednio do premiera Stołypina, z pominięciem prezydenta Zaremby. Po zbadaniu sprawy, 10 marca 1910 r. Ministerstwo Spraw Wewnętrznych w Petersburgu wydało rozkaz nr 4, w którym czytamy, że radcę stanu Mościckiego należy „uważać za zwolnionego na jego prośbę”. W konsekwencji oczyszczenia z zarzutów przyznano mu „emeryturę 6-kroć wyższą od wysłużonej - i zaliczono na służbę przy Ministerstwie Komunikacyi"101. W okresie walki o swoje dobre imię, Kajetan Mościcki cierpiał na chorobę oczu, która zakończyła się utratą wzroku ${ }^{102}$.

Dokonania Kajetana Mościckiego na rzecz miasta Warszawy podsumował dyrektor Tramwajów i Autobusów miasta Warszawy, były minister komunikacji Rzeczypospolitej Polskiej, inż. Alfons Kühn (1878-1944), który w 1933 r. napisał na łamach „Przeglądu Technicznego":

Z jego inicjatywy powstało laboratorjum mechaniczne do prób materjałów budowlanych, powstała miejska fabryka wyrobów betonowych, płyt chodnikowych i różnych części dla kanalizacji, powstał tartak miejski do wyrobu kostek drewnianych do ulepszonych bruków miejskich.

Ponadto dowiadujemy się, że z udziałem inżyniera Mościckiego

powstała w Warszawie elektrownia, powstały tramwaje elektryczne, rozszerzono znacznie kanalizację i wodociągi, wybudowano hale targowe, wiadukt i most ks. Poniatowskiego, rozszerzono ul. Karową, budując ślimak, łączący dolną część miasta z górną, założono park Ujazdowski, przebudowano gmach szkoły rzemieślniczej im. Konarskiego ${ }^{103}$ (Ryc. 12).

Gdy Kajetan Mościcki opuszczał zajmowane stanowisko, w Warszawie użytkowano 257 tys. $\mathrm{m}^{2}$ nawierzchni ulic wybrukowanych kostką drewnianą na podłożu betonowym i 705 tys. $\mathrm{m}^{2}$ chodników z płyt betonowych ${ }^{104}$.

Kajetan Mościcki przeniósł się z Warszawy do odziedziczonego po ojcu majątku Ławsk. Poświęcił się tam pracy twórczej. „W zaciszu domowem pracował niezmordowanie, opracowując przy pomocy sekretarza szereg dzieł naukowych, związanych z Jego specjalnością"105. W „Przeglądzie Technicznym” z 1911 r. znajdujemy artykuł inżyniera Mościckiego

100 L. Belmont, op. cit., s. 11.

101 lbid.

102 A. Kühn, Nekrologja. ś. p. Inż. Kajetan Mościcki, „Przegląd Techniczny” r. 59, 1933, nr 23, s. 604.

103 lbid.

104 „Kurjer Warszawski” r. 89, 1909, nr 199 Dodatek poranny, s. 2. Także: H. Janczewski, op. cit., s. 207.

105 Ś. p. inż. Kajetan Mościcki, op. cit. 


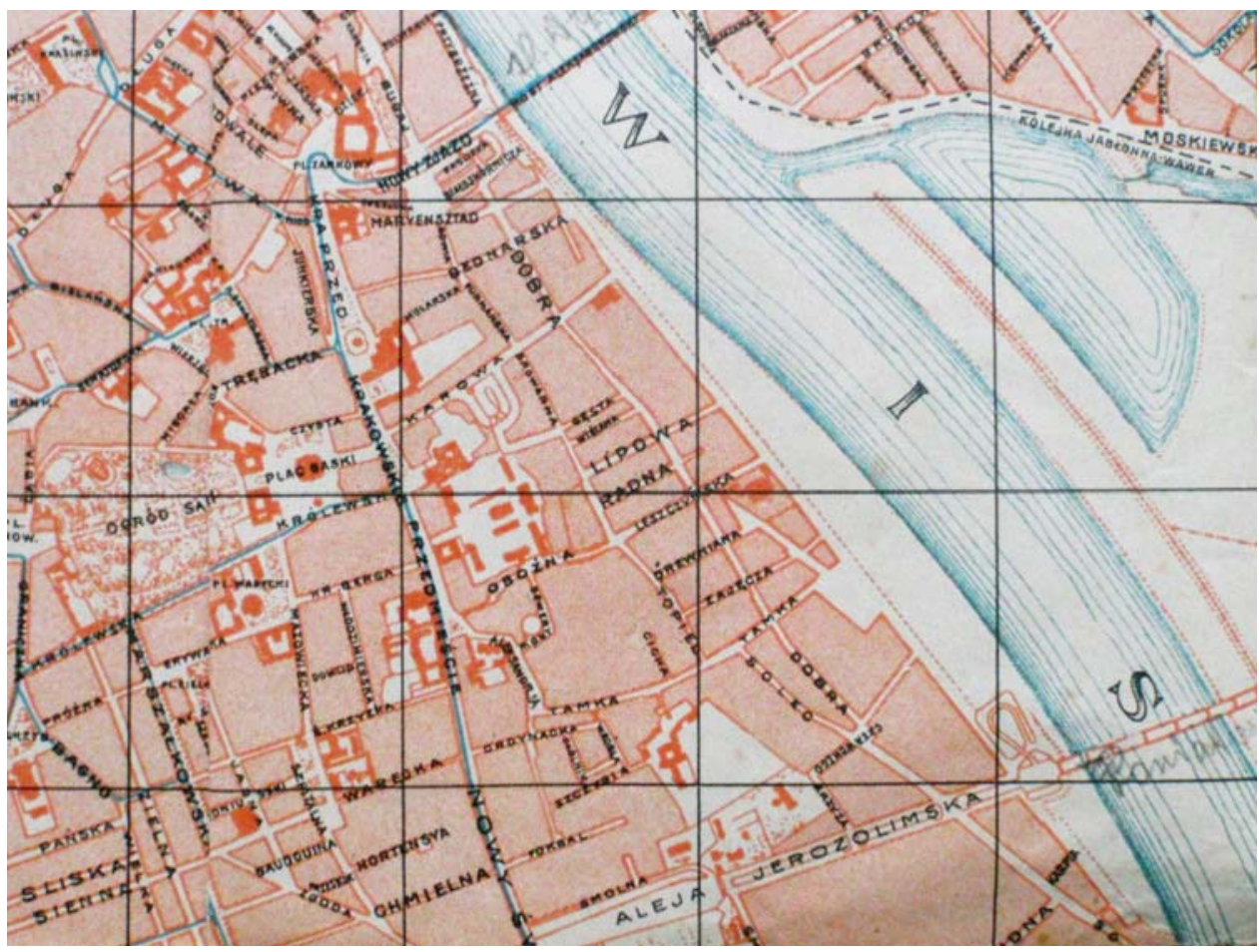

Ryc. 12. Fragment planu miasta Warszawy z oznaczonymi ślimakiem na ul. Karowej i Mostem Trzecim, Nakład Towarzystwa Doraźnej Pomocy Lekarskiej z 1912 r., Zakłady Graficzne B. Wierzbicki i S-ka w Warszawie (ze zbiorów autora).

pt. Wyprostowanie łuku koła sposobem graficznym, w którym przedstawił dostatecznie dokładne rozwiązanie tego zadania, dla łuków okręgu odpowiadających kątom środkowym tego okręgu o rozwartościach od $0^{\circ}$ do $180^{\circ}$. W artykule, autor wyprowadził wzory i podał przykłady obliczeń. Z podsumowania pracy dowiadujemy się, że „Opisany sposób wyprostowania łuku daje możliwość dzielenia łuku na dowolną ilość części równych sposobem graficznym"106. Opublikowana przez inż. Mościckiego metoda mogła więc znaleźć praktyczne zastosowanie zarówno przy budowie dróg i mostów usytuowanych w łuku, jak i do wyznaczania miejsc montażu przydrożnych urządzeń, takich jak latarnie czy balustrady.

Emerytowanego inżyniera miejskiego, a z zamiłowania wynalazcy, zapewne nadal nurtował problem ograniczenia przyczyn zbyt szybkiego niszczenia warszawskich bruków. Może o tym świadczyć treść artykułu na temat teorii tzw. kół sprężynowych, opublikowanego przez Kajetana Mościckiego w „Przeglądzie Technicznym” w 1917 r. Jego obszerną treść redakcja podzieliła na dziewięć części. W pierwszej z nich czytamy, że koła sztywne powodują niszczenie zarówno wozów, jak i nawierzchni dróg, a wysoki koszt obręczy gumowych zdaniem autora „stawać zawsze będzie na przeszkodzie powszechnemu ich 


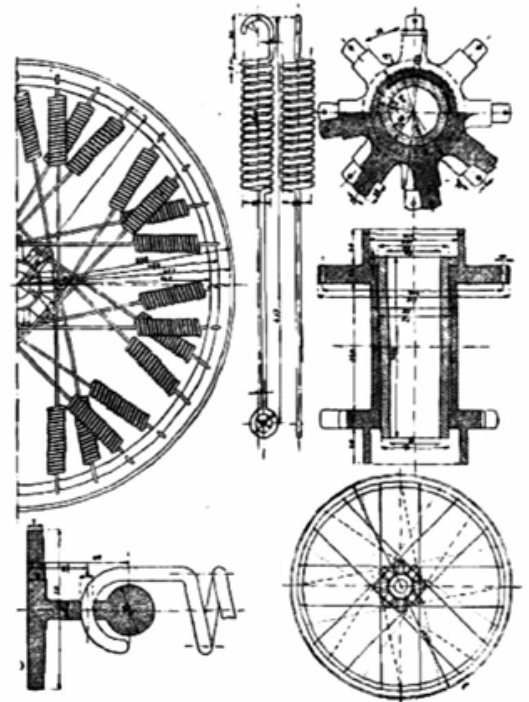

Ryc. 13. Projekt koła sprężynowego dla wozu ciężarowego z ładunkiem 3200 kg opublikowany przez inż. Mościckiego w „Przeglądzie Technicznym" z 1917 r. (Biblioteka Cyfrowa Politechniki Warszawskiej). zastosowaniu". Inżynier Mościcki zaproponował więc tańsze od gumowych koła sprężynowe, które „składają się z obręczy stalowej odpowiedniego kształtu i wymiarów, połączonej z piastą zapomocą sprężyn spiralnych" (Ryc. 13). Dalej autor artykułu wyprowadził wzory matematyczne i na podstawie wyników obliczeń dowodzit, że „Sprężyny te, jak również i sama obręcz działają jak resory, wskutek czego wozy zabezpieczone w zupełności będą od uderzeń martwych"107. Ostatnią część swojego dzieła inżynier Mościcki zakończył apelem: „Oddając pracę niniejszą na użytek ogółu, pragnąłbym bardzo, aby technicy, zawodowcy i fabrykanci zechcieli zwrócić na nią swoją uwagę i swoją wspólną pracą pomogli do rozwiązania jednego z bardzo ważnych zadań techniki, nie tylko pod względem teoretycznym, lecz także praktycznym"108. Sam fakt opublikowania tak obszernego opracowania przez prestiżowy tygodnik naukowo-techniczny świadczy o zainteresowaniu, jakie w środowisku inżynierów komunikacji wzbudzał omawiany temat. Wyniki zaprezentowanych prac nie zostały jednak wykorzystane w praktyce, ponieważ badania nad syntezą taniego sztucznego kauczuku, prowadzone między innymi w Polsce przez inżyniera Wacława Szuszkiewicza (1896-1992) z Chemicznego Instytutu Badawczego, a potem uruchomienie jego produkcji w Fabryce Gum Jezdnych w Dębicy spowodowały upowszechnienie się rozwiązania technicznego konkurencyjnego w stosunku do kół sprężynowych - gumowych opon pneumatycznych.

W Ławsku Kajetan Mościcki doczekał dnia 11 listopada 1918 r., w którym Rzeczpospolita Polska odrodziła się po 123 latach rozbiorów. W niepodległej Polsce przeprowadził modernizację swojego majątku Ławsk, w którym do 1920 r. zbudował cukrownię i gorzelnię. W celu szerszego rozwijania przemysłu przetwórstwa rolniczego na obszarze rodzimego powiatu zaangażował się w utworzenie spółki akcyjnej Syndykat Rolniczy Szczuczyński. Zajmował się również pracami teoretycznymi z dziedziny matematyki, takimi jak „Rozwiązanie funkcyj eliptycznych”. Ostatnim z jego wielu wynalazków był nowy typ silnika parowego, którego model wykonał i opatentował, lecz nie zdążył już opublikować w prasie technicznej ${ }^{109}$.

U schyłku życia, w czerwcu 1931 r., część swojego majątku Kajetan Mościcki postanowił przekazać aktem notarialnym Polskiej Akademii Umiejętności, tworząc fundusz imienia zmarłej żony Janiny z Rychterów Mościckiej, „składający się z akcyj Banku Pol-

107 Idem, Koła sprężynowe, „Przegląd Techniczny” r. 43, 1917, nr 31-32, s. 261-264.

108 lbid., nr 49-50, s. 396.

109 A. Kühn, op. cit. 
skiego i listów zastawnych na łączną kwotę 400.000 zł. i dwóch kamienic w Warszawie". Odsetki od kapitału miały zostać przeznaczone, „począwszy od r. 1934, na nagrodę za pracę naukową przez Polaka napisaną, z dziedziny matematyki i astronomji, albo fizyki, albo chemji, albo wreszcie biologji, przynoszącą wybitne odkrycie naukowe"110. Dopiero w 1939 r. Polska Akademia Umiejętności po raz pierwszy przyznała tę nagrodę w kwocie 20000 zł, a jej laureatem został matematyk Stefan Banach (1892-1945), profesor Uniwersytetu Jana Kazimierza we Lwowie ${ }^{111}$.

Kajetan Mościcki zmarł 19 października 1933 r. przeżywszy 77 lat. Po mszy w kościele św. Karola Boromeusza 23 października został pochowany na Cmentarzu Powązkowskim w Warszawie. W nekrologu opublikowanym w „Przeglądzie Technicznym” inżynier Alfons Kühn napisał: „Opuścił sze-

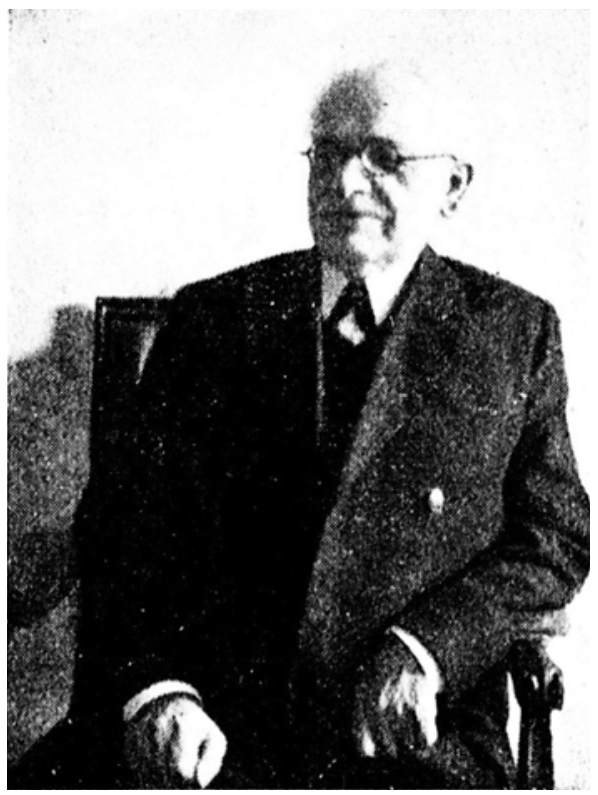

Ryc. 14. Inżynier Kajetan Mościcki u schyłku życia na fotografii w tygodniku ilustrowanym „Świat" z 1933 r. (Mazowiecka Biblioteka Cyfrowa). regi żyjących człowiek, którego cechowały nieskazitelna prawość, fanatyzm pracy, głęboka wiedza, wyjątkowa skromność, dobroć, niezwykły hart ducha i szczere umiłowanie kraju"112. W jednym z dwóch nekrologów, które zamieścił na swoich łamach „Kurjer Warszawski” czytamy:

Pozostawia po sobie żal serdeczny i dobrą pamięć, jako człowiek zacny, chętnie śpieszący z pomocą innym skromnie, bez rozgłosu. Wielu kształcących się w szkołach publicznych uczniów dzięki ś. p. Mościckiemu udało się dokończyć wykształcenia. Akademja Umiejętności zaś zawdzięczać będzie zmarłemu hojny zapis, jaki dla niej uczynił ${ }^{113}$.

W uznaniu zasług dla Warszawy magistrat miasta stołecznego nadał jednej z ulic, rozbudowującego się wówczas Żoliborza, imię Kajetana Mościckiego ${ }^{114}$. Po drugiej wojnie światowej dwukrotnie zmieniano nazwę ulicy, która nie powróciła jednak do imienia swojego zasłużonego dla Warszawy patrona.

110 Roczny plon nauki polskiej. Uroczyste posiedzenie Polskiej Akademji Umiejętności, „Ilustrowany Kuryer Codzienny" r. 22, 1931, nr 163, s. 4.

111 J. Piłatowicz, S. Świerzewski, op. cit., s. 150.

112 A. Kühn, op. cit.

113 „Kurjer Warszawski” r. 113, 1933, nr 291, s. 4, nr 290, s. 9

114 Obecnie jest to ulica Sarmatów, przy której znajduje się Teatr Komedia. 


\section{Bibliografia}

\section{Źródła}

Bajkiewicz J., Historia budowy Mostu Poniatowskiego i tragedia jego twórcy, „Stolica: Warszawski Tygodnik Ilustrowany" r. 14, nr 23, 6 VI 1959 r., s. 14-15.

Belmont L., Na kanwie skargi do l-go Departamentu Senatu, „Wolne Słowo”, r. 5, 1912, nr 167-168, s. 3-32.

Bruki warszawskie, „Głos” t. 1, nr 15, 11 IV 1896 r., s. 353-356.

„Czytelnia Niedzielna" r. 5, nr 44, 28 X 1860 r., s. 374.

Gierymski A., Wodociąg przy zbiegu Krak.-Przedmieścia i ul. Karowej, „Tygodnik Powszechny" r. 7, nr 21, 27 V 1883 r., s. 329.

Gordziałkowski W., Kostka drzewna jako materiał na nawierzchnię mostów dla ruchu kołowego, „Przegląd Komunikacyjny” 1945, nr 5, s.150-152.

Koleżak W., Powiśle Warszawy, „Wędrowiec” r. 38, nr 31, 4 VIII 1900 r., s. 606-609.

Kühn A., Nekrologja. ś. p. Inż. Kajetan Mościcki, „Przegląd Techniczny”, r. 59, nr 23, 22 XI 1933 r., s. 604.

„Kurjer Warszawski" r. 52, nr 141, 28 VI 1872 r., s. 2; r. 69, nr 50, 19 II 1889 r., Dodatek poranny, s. 1-2; r. 72, nr 172, 23 VI 1892 r., Dodatek poranny, s.1; r. 72, nr 282, $11 \mathrm{X}$ 1892 r., s. 4; r. 73, nr 262, 22 IX 1893 r., s. 1; r. 74, nr 98, 10 IV 1894 r., s. 4; r. 74, nr 106, 18 IV 1894 r., Dodatek poranny, s. 1; r. 74, nr 266, 26 IX 1894 r., s. 4; r. 74, nr 282, 12 X 1894 r., s. 5; r. 74, nr 299, 29 X 1894 r., s. 3; r. 75, nr 167, 19 VI 1895 r., s. 4; r. 76, nr 221, 11 VIII 1896 r., Dodatek poranny, s. 1-2.; r. 76, nr 223, 13 VIII 1896 r., Dodatek poranny, s. 1; r. 77, nr 257, 17 IX 1897 r., Dodatek poranny, s. 1; r. 78, nr 312, 11 XI 1898 r., s. 4; r. 81, nr 105, 15 IV 1897 r., Dodatek poranny, s. 1; r. 81, nr 216, 25 VII 1901 r., s. 3; r. 89 , nr 40, 9 II 1909 r., s. 1; r. 89, nr 153, 5 VI 1909 r., Dodatek poranny, s. 2; r. 89 , nr 167, 19 VI 1909 r., s. 7; r. 89, nr 181, 3 VII 1909 r., Dodatek poranny, s. 1; r. 89 , nr 197, 19 VII 1909 r., s. 3; r. 89 , nr 205, 27 VII 1909 r., s. 4; r. 89, nr 233, 24 VIII 1909 r., Dodatek poranny, s. 1; r. 89, nr 233, 24 VIII 1909 r., s. 3; r. 113, nr 291, 21 X 1933 r., s. 4; r. 113, nr 290, $20 \times 1933$ r., s. 9.

Mościcki K., Polemika. Sprawy miejskie, „Przegląd Tygodniowy Życia Społecznego Literatury i Sztuk Pięknych" r. 31, nr 11, 14 III 1896 r., s. 131-132; nr 12, 21 III 1896 r., s. 142-143; nr 13, 28 III 1896 r., s. 155-156.

Mościcki K., Wyprostowanie koła sposobem graficznym, „Przegląd Techniczny” r. 37, nr 2, 12 I 1911 r., s. 18-19.

Mościcki K., Koła sprężynowe, „Przegląd Techniczny” r. 43, nr 31-32, 7 VIII 1917 r., s. 261264; nr 33-34, 21 VIII 1917 r., s. 278-280; nr 35-36, 4 IX 1917 r., s. 296-298 ; nr 3738, 18 IX 1917 r., s. 309-311; nr 39-40, 2 X1917 r., s. 327-329; nr 43-44, 30 X 1917 r., s. 358-359; nr 45-46, 13 XI 1917 r, s. 370-372; nr 47-48, 27 XI 1917 r., s. 383-384; nr 49-50, 11 XII 1917 r., s. 395-396.

Patent No. 546,770, Kajetan Mościcki (Warsaw, Russia), „Official Gazette of the United States Patent Office" 1895.

Podkowa S., W sprawie bruków w Warszawie, „Przegląd Tygodniowy Życia Społecznego Literatury i Sztuk Pięknych" r. 28, nr 10, 11 III 1893 r., s. 110-111.

Prus B., Kronika tygodniowa, „Kuryer Codzienny” r. 33, nr 101, 11 IV 1897 r., s. 1.

Prus B., Prus o „Wolnem Słowie”, „Wolne Słowo” r. 5, nr 166, 1 VI 1912 r., s. 2. 
Przybylski A., O zastosowaniu bruku drobnokostkowego na drogach podmiejskich, „Przegląd Techniczny" r. 43, nr 21-22, 29 V 1917 r., s. 177-178, nr 25-26, 26 VI 1917 r., s. 219-220.

Roboty miejskie w Warszawie, „Przegląd Techniczny” r. 4, 1878, t. 7, s. 179-180.

Roczny plon nauki polskiej. Uroczyste posiedzenie Polskiej Akademji Umiejętności, „Ilustrowany Kuryer Codzienny" r. 22, nr 163, 15 VI 1931 r., s. 3-5.

Sprawy miejskie, „Przegląd Tygodniowy Życia Społecznego Literatury i Sztuk Pięknych” r. 31, nr 8, 22 II 1896 r., s. 89-90.

Sznuk Z., Bruki i sposób gospodarowania niemi w Warszawie, „Przegląd Techniczny” r. 43, nr 25-26, 26 VI 1917 r., s. 215-216; nr 29-30, 24 VII 1917 r., s. 254-256; nr 33-34, 21 VIII 1917 r., s. 278-280.

Ślimak Warszawski, „Życie i Sztuka. Pismo dodatkowe, ilustrowane. Kraj” 1904, nr 46, 25 XI 1904 r., s. 10-11.

Ś. p. inż. Kajetan Mościcki, „Świat” r. 28, nr 44, 4 XI 1933 r., s. 20.

Ulica Karowa, "Tygodnik Illustrowany” r. 36, nr 50, 11 XII 1895 r., s. 438.

Warszawa. Nowa dzielnica, przy ulicy Karowej, „Biesiada Literacka” t. 42, nr 32, 26 VII 1896 r., s. 84.

Wawrykiewicz E., Bibliografia trzydziestu siedmiu tomów Przeglądu Technicznego na lat XXV (1875-1899), Warszawa 1903.

Wykształcenie techniczne, „Przegląd Techniczny” r. 4, 1878, t. 7, s. 253.

II-ga Wystawa Hygieniczna w Warszawie przed otwarciem, „Tygodnik Illustrowany" r. 37, nr 18, 2 V 1896 r., s. 345.

\section{Literatura przedmiotu}

Chwaściński B., Mościcki Kajetan Kazimierz, [w:] Słownik Biograficzny Techników Polskich t. 7, 1996, s. 93-94.

Chwaściński B., Mosty na Wiśle i ich budowniczowie, Warszawa 1997.

Dragański K., Żbikowski J., Spotkania z historią Polskiego Towarzystwa Higienicznego/Encounters with the history of the Polish Society of Hygiene - Dr. Stanisław Markiewicz, „Hygeia Public Health" 2011, 46(4), s. 502-505.

Dziewulski S., Radziszewski H., Warszawa, Warszawa 1913.

Janczewski H., Warszawa. Geneza i rozwój inżynierii miejskiej, Warszawa 1971.

Jankowski J., Mosty w Polsce i mostowcy polscy (od czasów najdawniejszych do końca I wojny światowej), Wrocław 1973.

Jankowski J., Pięćdziesięciolecie mostu im. ks. Józefa Poniatowskiego, "Stolica: Warszawski Tygodnik Ilustrowany" r. 19, nr 8, 23 II 1964 r., s. 2.

Kałamajska-Saeed M., Wiadukt ulicy Karowej w Warszawie, „Kwartalnik Architektury i Urbanistyki" r. 22, 1977, nr 2, s. 149-160.

Kozak Z., Sznuk Stefan Mieczysław, [w:] Polski Słownik Biograficzny t. 48/3, 2012, s. 469471.

Mistewicz M., Pierwsze w Królestwie Polskim łukowe mosty systemu Moniera zbudowane przez inżyniera Arnolda Bronikowskiego, „Kwartalnik Historii Nauki i Techniki” t. 64, 2019, nr 1, s. 39-55, DOI 10.4467/0023589XKHNT.19.002.10110.

Nietyksza M., Ludność Warszawy na Przełomie XIX i XX wieku, Warszawa 1971.

Omilianowska M., Most i wiadukt księcia Józefa Poniatowskiego, Warszawa 1991. 
Piłatowicz J., Świerzewski S., Mościcki Kajetan Kazimierz, [w:] Polski Słownik Biograficzny t. 22/1, z. 92, 1977, s. 149-150.

Most i wiadukt imienia ks. Józefa Poniatowskiego przez rzekę Wisłę w Warszawie [brak autora], Warszawa 1927.

Słoniowa A., Początki Nowoczesnej Infrastruktury Warszawy, Warszawa 1978.

Sterner W., Mosty Warszawy, Warszawa 1960.

Walczak D., Warszawskie tramwaje konne 1866-1908, [b.m.w.] 2016

Żelichowski R., Lindleyowie. Dzieje inżynierskiego rodu, Warszawa 2002.

Żelichowski R., Weszpiński P.E., William Heerlein Lindley. Plan Warszawy 1912, Plan niwelacyjny miasta Warszawy. Zdjęcie pod kierunkiem Głównego Inżyniera W. H. Lindleya, Warszawa 2016.

Dr hab. inż. Marek Mistewicz jest profesorem Instytutu Badawczego Dróg i Mostów w Warszawie. Ukończył studia wyższe na Wydziale Inżynierii Lądowej Politechniki Warszawskiej, a w 2012 r. obronił rozprawę doktorską na Wydziale Architektury tej samej uczelni. W roku 2019 Rada Naukowa Instytutu Historii Nauki im. Ludwika i Aleksandra Birkenmajerów nadała mu tytuł doktora habilitowanego. Pełnił między innymi funkcje: Naczelnego Dyrektora Zarządu Dróg Miejskich w Warszawie, Prezesa Biura Projektowo-Badawczego Dróg i Mostów TransprojektWarszawa Sp. z o.o. oraz Zastępcy Generalnego Dyrektora Dróg Publicznych. Jest autorem dwóch monografii z dziedziny historii techniki oraz około osiemdziesięciu artykułów w czasopismach naukowych i naukowo-technicznych, rozdziałów w książkach i referatów opublikowanych w księgach konferencyjnych, na tematy związane m.in. z teorią zarządzania mostami, utrzymaniem dróg i mostów oraz historią techniki mostowej.

e-mail: mmistewicz@ibdim.edu.pl

Data zgłoszenia artykułu: 9 maja 2019

Data przyjęcia do druku: 7 czerwca 2019 